\title{
Test Plan for Evaluating Hammer and Fixed Cutter Grinders Using Multiple Varieties and Moistures of Biomass Feedstock
}

July 2007

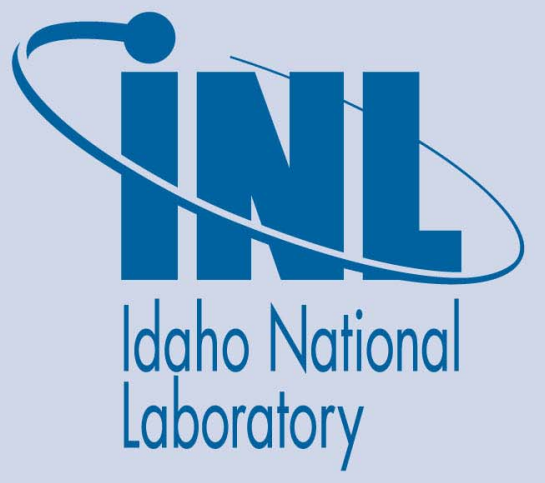

The INL is a U.S. Department of Energy National Laboratory operated by Battelle Energy Alliance 
INL/EXT-07-12808

\title{
Test Plan for Evaluating Hammer and Fixed Cutter Grinders Using Multiple Varieties and Moistures of Biomass Feedstock
}

July 2007

\author{
Idaho National Laboratory \\ Bioenergy Feedstock Infrastructure Project \\ Idaho Falls, Idaho 83415
}

Prepared for the

U.S. Department of Energy

Assistant Secretary for Energy Efficiency and Renewable Energy

Under DOE Idaho Operations Office

Contract DE-AC07-05ID14517 


\section{DISCLAIMER}

This information was prepared as an account of work sponsored by an agency of the U.S. Government. Neither the U.S. Government nor any agency thereof, nor any of their employees, makes any warranty, expressed or implied, or assumes any legal liability or responsibility for the accuracy, completeness, or usefulness, of any information, apparatus, product, or process disclosed, or represents that its use would not infringe privately owned rights. References herein to any specific commercial product, process, or service by trade name, trade mark, manufacturer, or otherwise, does not necessarily constitute or imply its endorsement, recommendation, or favoring by the U.S. Government or any agency thereof. The views and opinions of authors expressed herein do not necessarily state or reflect those of the U.S. Government or any agency thereof. 



\section{Bioenergy Feedstock Infrastructure Project}

\section{Test Plan for Evaluating Hammer and Fixed Cutter Grinders Using Multiple Varieties and Moistures of Biomass Feedstock}

INL/EXT-07-12808

July 2007

Approved by:

Christopher Wright

Date

Project Engineer, Principle Investigator

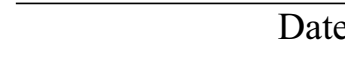

Kevin Kenney

Date

Project Engineer

Richard Hess

Date

Project Manager 



\section{SUMMARY}

Biomass preprocessing is a critical operation in the preparation of feedstock for the front-end of a cellulosic ethanol biorefinery. Its purpose is to chop, grind, or otherwise format the biomass material into a suitable feedstock for optimum conversion to ethanol and other bioproducts. Without this operation, the natural size, bulk density, and flowability characteristics of harvested biomass would decrease the capacities and efficiencies of feedstock assembly unit operations and biorefinery conversion processes to the degree that programmatic cost targets could not be met. The preprocessing unit operation produces a bulk flowable material that 1) improves handling and conveying efficiencies throughout the feedstock assembly system and biorefinery 2) increases biomass surface areas for improved pretreatment efficiencies, 3 ) reduces particle sizes for improved feedstock uniformity and density, and 4) fractionates structural components for improved compositional quality.

The Idaho National Laboratory (INL) is tasked with defining the overall efficiency/effectiveness of current commercial hammer and fixed cutter grinding systems and other connecting systems such as harvest and collection, storage, transportation, and handling for a wide variety of feedstock types used in bioethanol or syngas production.

This test plan details tasks and activities for two separate full-scale grinding tests: Material Characterization Test and Machine Characterization Test. For the Material Characterization Test, a small amount ( 5-7 tons each) of several feedstock varieties will be ground. This test will define the fractionation characteristics of the grinder that affect the bulk density, particle size distribution, and quality of the size reduced biomass resulting from different separation screen sizes. A specific screen size will be selected based on the characteristics of the ground material. The Machine Characterization Test will then use this selected screen to grind several 30-ton batches of different feedstock varieties and moistures. This test will focus on identifying the performance parameters of the grinding system specific to the feed, fractionation, and screen separation components and their affect on machine capacity and efficiency. 


\section{CONTENTS}

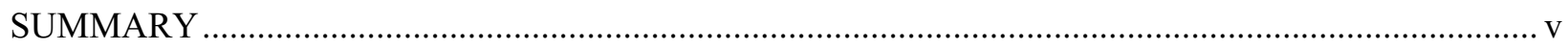

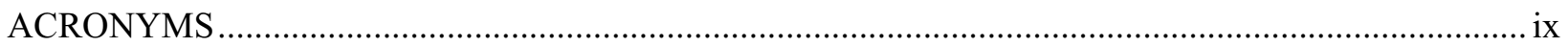

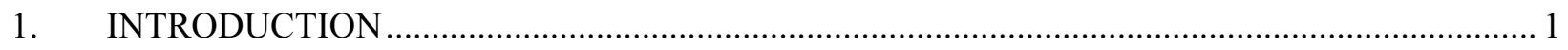

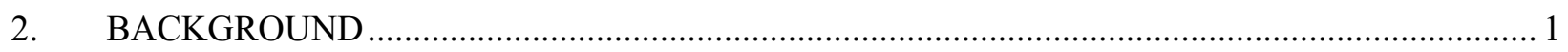

2.1 DOE Program Overview .............................................................................................. 1

2.2 The Idaho National Laboratory Biomass Work ….............................................................. 2

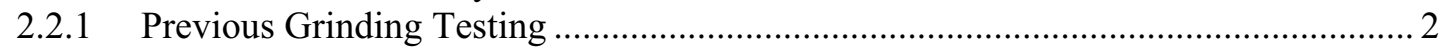

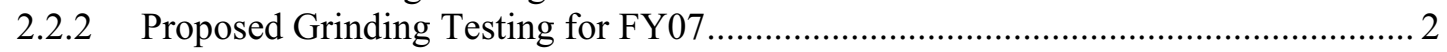

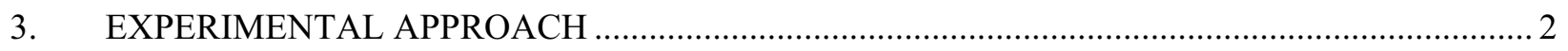

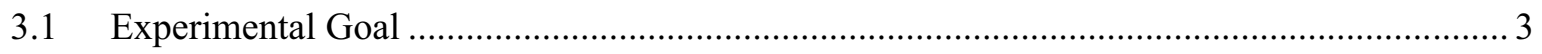

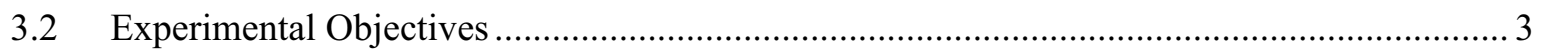

3.3 Project and Experimental Tasks................................................................................. 4

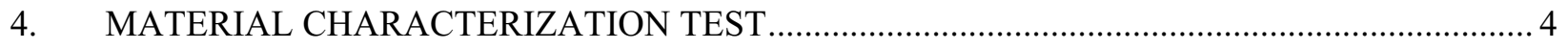

4.1 Define Tasks and Requirements............................................................................... 4

4.1.1 Review Test Plan with Grinder Manufacturer ..................................................... 5

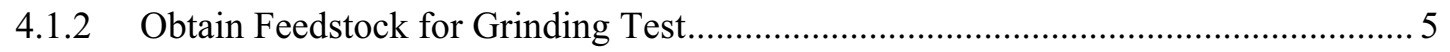

4.1.3 Define Material Characterization Grinding Tests .................................................. 6

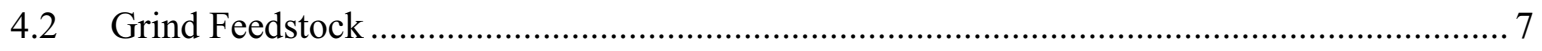

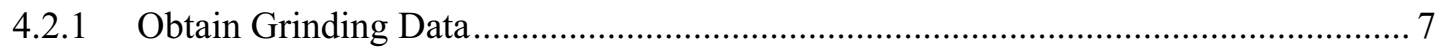

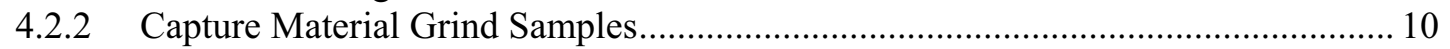

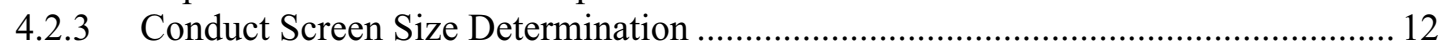

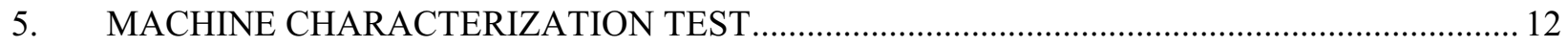

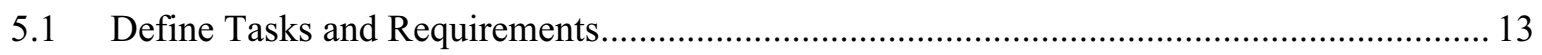

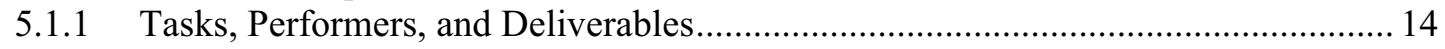

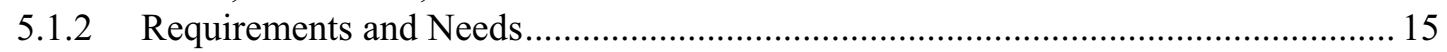

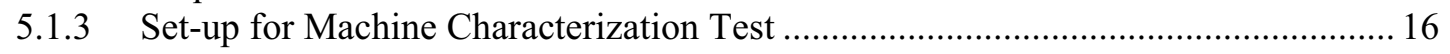

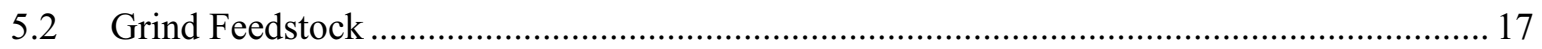

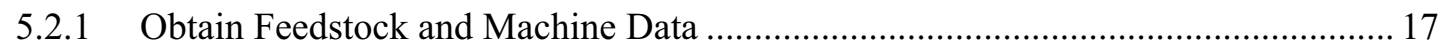

5.2.2 Capture Material Grind Samples.......................................................................... 26

5.2.3 Conduct Data Reduction and Sample Analysis ................................................... 29

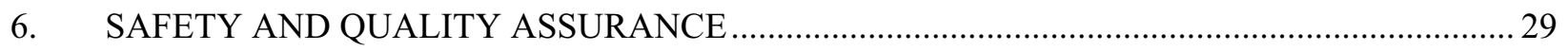

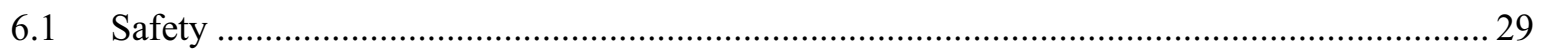

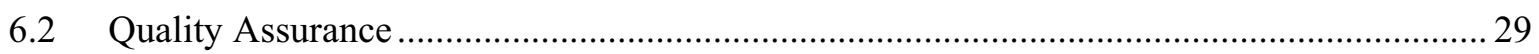

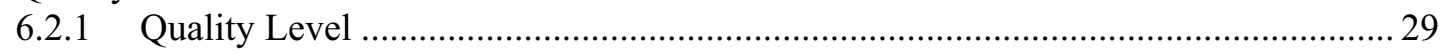

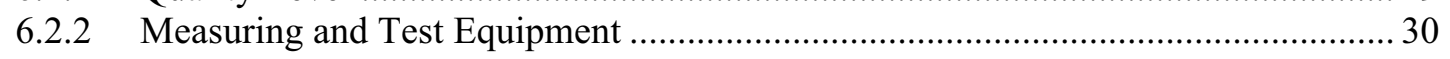

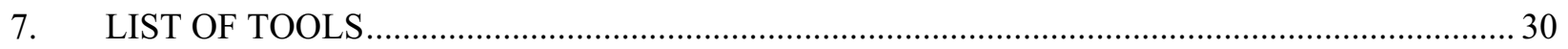

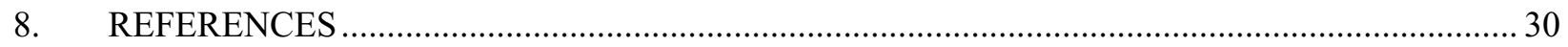




\section{FIGURES}

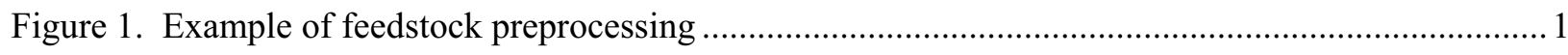

Figure 2. Diamond Z 1352B 860 hp Tub Grinder with forage hammers............................................ 2

Figure 3. General experimental tasks and activities of the draft test plan .............................................. 4

Figure 4. An example of bale pedigree ......................................................................................... 8

Figure 5. An example of Equipment/Hardware Logbook data page ...................................................... 9

Figure 6. An example page of the Sample Logbook............................................................................. 9

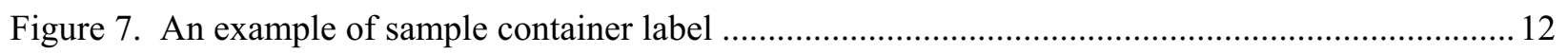

Figure 8. Machine characterization test resource requirements and needs ............................................. 15

Figure 9. An example page of the Feedstock Materials Data Logbook................................................. 18

Figure 10. An example page of the Equipment/Hardware Logbook. ................................................... 19

Figure 11. An example of Equipment/Hardware Logbook data page.................................................20

Figure 12. An example of truck and trailer page in the Equipment/Hardware Logbook........................2 21

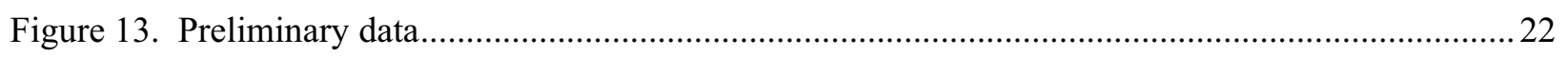

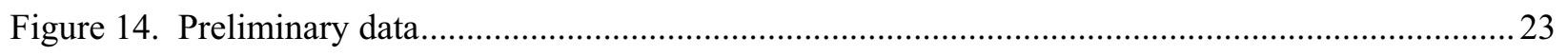

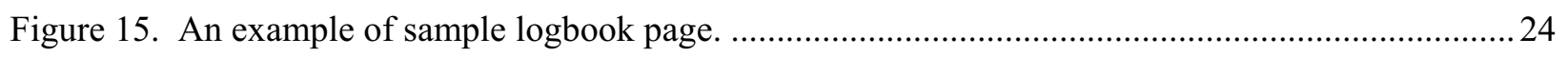

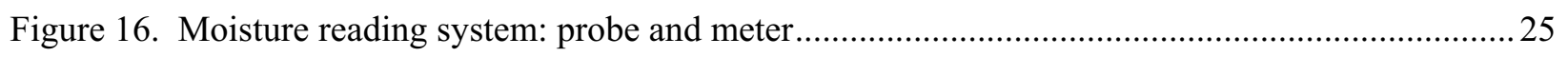

Figure 17. Commercial temperature reading system: probe and meter ...............................................25

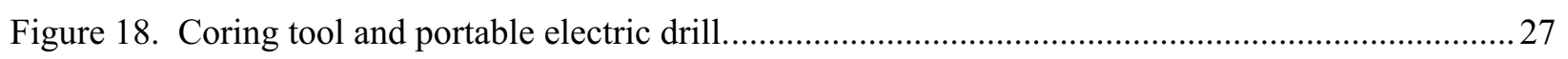

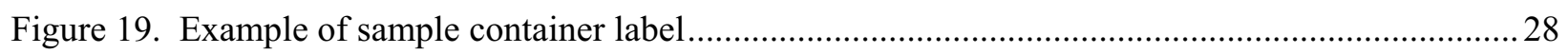

TABLES

Table 1. Section 4.1.1 general tasks, performers and deliverables ........................................................5

Table 2. Section 4.1.2 general tasks, performers and deliverables ........................................................ 6

Table 3. Section 4.1.3 general tasks, performers and deliverables ........................................................ 6

Table 4. Section 5.1.1 general tasks, performers and deliverables ...................................................... 14

Table 5. Section 5.1.3 general tasks, performers and deliverables ....................................................... 16

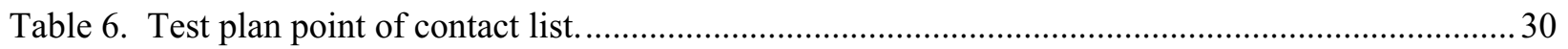




\section{ACRONYMS}

CRADA Cooperative Research and Development Agreements

DOE Department of Energy

INL Idaho National Laboratory

IHR Independent Hazard Review

M\&TE Measuring and Test Equipment

PPE Personal Protection Equipment

QA Quality Assurance

USDA United States Department of Agriculture

UPS United Parcel Service 


\section{Test Plan for Evaluating Hammer and Fixed Cutter Grinders Using Multiple Varieties and Moistures of Biomass Feedstock}

\section{INTRODUCTION}

Biomass preprocessing is a critical operation in the preparation of feedstock for the front-end of a cellulosic ethanol biorefinery. Its purpose is to chop, grind, or otherwise format the biomass material into a suitable feedstock for conversion to ethanol and other bioproducts. (See Figure 1) Without this operation, the natural size, bulk density, and flowability characteristics of harvested biomass would decrease the capacities and efficiencies of feedstock assembly unit operations and biorefinery conversion processes to the degree that programmatic cost targets could not be met. Thus, the preprocessing unit operation produces a bulk flowable material that 1) improves handling and conveying efficiencies throughout the feedstock assembly system and biorefinery 2) increases biomass surface areas for improved pretreatment efficiencies, 3) reduces particle sizes for improved feedstock uniformity and density, and 4) fractionates structural components for improved compositional quality. In addition, the preprocessing operation has the potential to change traditional methodologies for collection, handling, and transporting biomass that leads to revolutionary improvements in the feedstock assembly system.

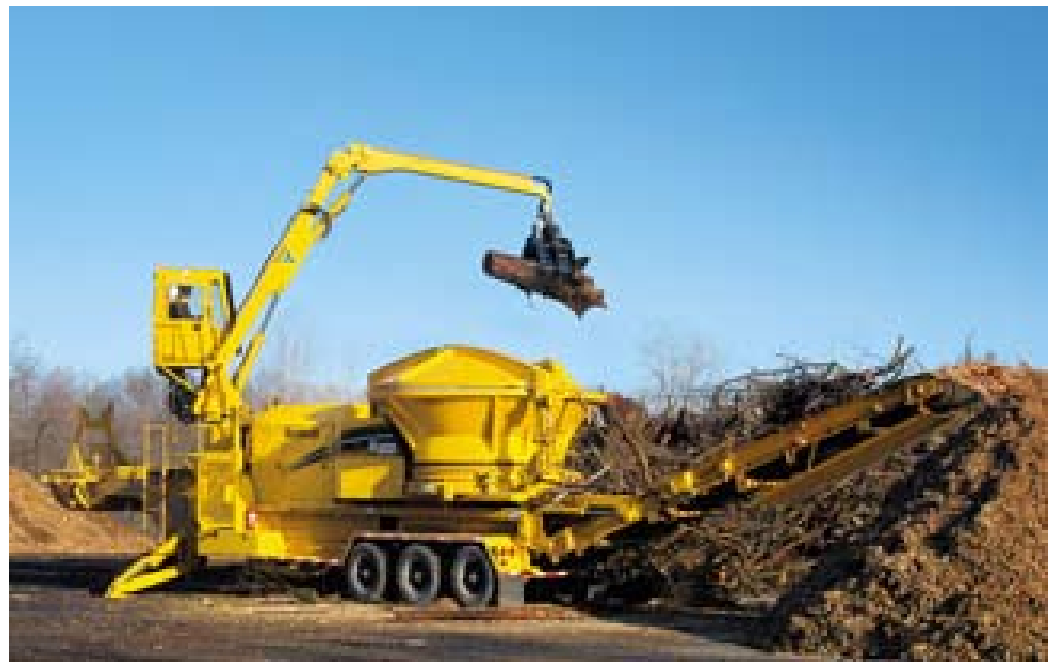

Figure 1. Example of feedstock preprocessing

\section{BACKGROUND}

\subsection{DOE Program Overview}

The U.S. Department of Energy (USDOE) and the U.S. Department of Agriculture (USDA) are both strongly committed to expanding the role of biomass as an energy source. In particular, they support biomass fuels and products to reduce the need for oil and gas imports; to support the growth of agriculture, forestry, and rural economies; and to foster major new domestic industries — biorefineries making a variety of fuels, chemicals, and other products. 


\subsection{The Idaho National Laboratory Biomass Work}

The Idaho National Laboratory (INL) is tasked with improving the overall efficiency of the feedstock assembly system including the harvest and collection, storage, preprocessing (grinding), transportation, and handling unit operations for all feedstock types used in bioethanol or syngas production.

\subsubsection{Previous Grinding Testing}

Field grinding tests were conducted in FY04 [1] [2] using Diamond Z 1352B and 1350L mobile grinders. (See Figure 2) The tests consisted of running $\sim 1000$ lbs 4'x4'x8' square bales of barley straw through six different grinder screen size configurations. The test configurations were designed to demonstrate hammer and fixed cutter grinder performance targets for a capacity of 30 tons/hour, particle size of 1/4-inch minus, and bulk density of $8 \mathrm{lbs} \mathrm{ft}^{-3}$ or greater.

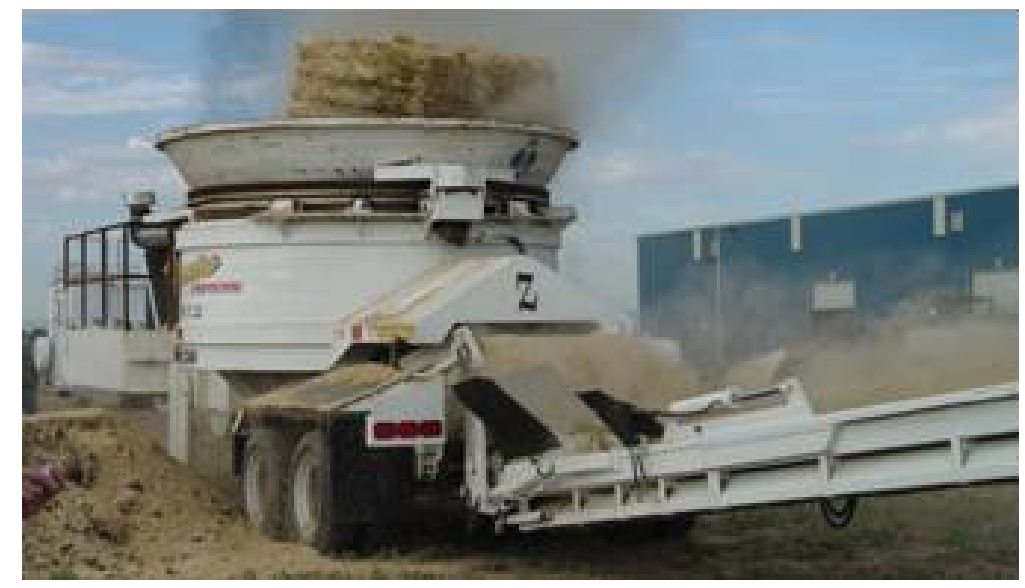

Figure 2. Diamond Z 1352B 860 hp Tub Grinder with forage hammers

\subsubsection{Proposed Grinding Testing for FY07}

The next step in full-scale grinding research is to collect hammer and fixed cutter grinder performance data for different grinder technologies on multiple feedstock varieties and moisture levels. This work will focus on identifying the performance parameters of three aspects of a grinding system, specifically the feed, fractionation, and screen separation systems. In addition, this work will use fundamental bulk biomass characterization methods to help improve and eventually optimize the performance parameters of each aspect of a grinding machine. The final feedstock assembly system design will identify a clear path to demonstrate and validate the preprocessing unit operation by FY09.

\section{EXPERIMENTAL APPROACH}

The research outlined in this test plan will help the INL understand the factors affecting the optimum capacity, efficiency, and biomass quality for different feedstock preprocessing equipment configurations and different feedstock varieties. The results of this testing will be directly used in INL's technoeconomic evaluation of the entire feedstock assembly system to help determine the cost, quality, and logistical impacts of the preprocessing unit operation. 


\subsection{Experimental Goal}

In 2007, perform full-scale grinding field tests to quantify and qualify current preprocessing equipment capacities, efficiencies and the quality of the resulting ground biomass for multiple biomass feedstock varieties and moisture levels.

\subsection{Experimental Objectives}

The objectives of this research are to:

- Establish relationships with grinder manufacturers that lead to partnerships to design and fabricate a full-scale prototype research grinder capable of testing advanced configurations and feedstock varieties.

- Determine achievable performance parameters, at a minimum, for wheat straw, switchgrass, corn stover, and sorghum stover feedstocks with various moisture contents.

- Develop the functional relationships between preprocessing hardware configurations and the natural structure of the feedstock materials in order to optimize the preprocessing unit operation.

- Identify specific feed configurations/limitations or a range of operating parameters to help meet overall system capacity and efficiency criteria.

- Identify specific grinder fractionation mechanisms that can be optimized to help meet overall system capacity and efficiency criteria.

- Identify the performance parameters of a separation system that can be coupled to a preprocessing operation and take advantage of value-add fractions.

- Expand the understanding of preprocessing tissue deconstruction and its relationship to grinder configuration, tissue fractions, tissue moisture, and grinder capacity, in order to optimize grinder configurations for capacity, efficiency, and quality.

- Provide sample material to explore fundamental rheological properties of preprocessed feedstocks, including uniformity, compactability, and flowability, to the design, performance, and cost of the entire preprocessing operation.

- Provide sample material to help identify strategies to increase bulk densities of preprocessed feedstocks by coupling the understanding of biomass deconstruction and rheological properties with innovative bulk compaction methods.

- Quantify physical biomass losses due to dust and leaks in the grinding and conveying systems to better determine net grinder efficiency and product quality.

- Examine the drying capacity of full-scale grinding operations to determine its impact on biomass moisture content with respect to applied feedstock assembly system technologies and cost.

- Develop information that defines critical hardware parameters, design specifications, and instrumentation needed to develop a prototype research grinder capable of testing multiple feedstock varieties. 
- Explore validation protocols that need to be established so that preprocessing can effectively be tested and validated in FY09.

\subsection{Project and Experimental Tasks}

This test plan, and its extensive analysis activities, achieves the above listed objectives. The execution of the test plan is divided into two general tests with supporting tasks and subtasks. These are shown in Figure 3. The details of these two tests are discussed in the subsequent sections of the test plan. All of the tasks and activities for the Material Characterization Test are shown in Section 4 and all of the tasks and activities of the Machine Characterization Test are shown in Section 5.

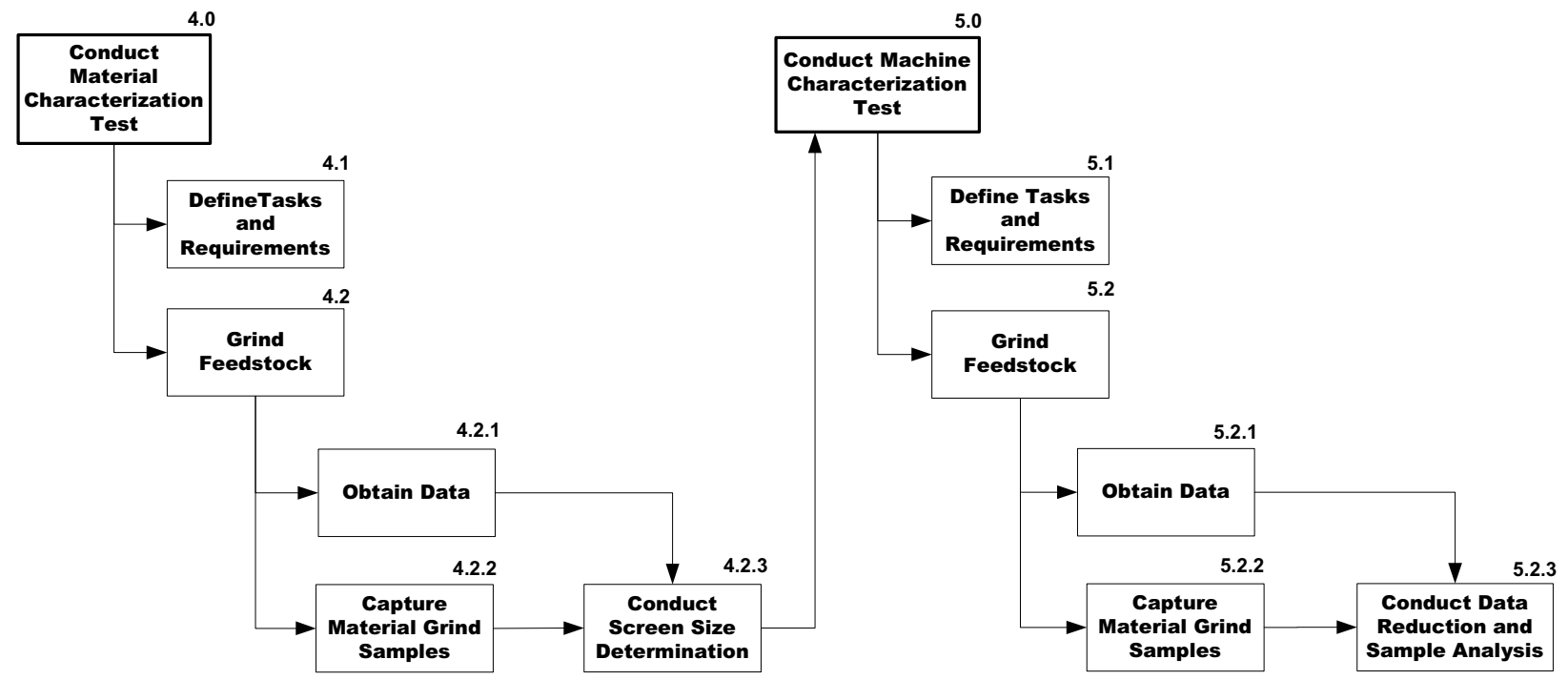

Figure 3. General experimental tasks and activities of the draft test plan

\section{MATERIAL CHARACTERIZATION TEST}

The goals of the Material Characterization Test are to characterize the operational aspects/attributes of current hammer and fixed cutter grinder technologies and to generate feed stock samples to characterize the deconstruction profile. Grinding information collected from each grinder screen size characterizes a number of physical properties of the feedstock material and will help define the optimum grinding screen for a variety of feedstocks preparatory to the Machine Characterization Test.

The tasks and activities of the Material Characterization Test include:

- Define tasks and requirements

- Grind feedstock

- Obtain grinding data

- Obtain material grind samples

\subsection{Define Tasks and Requirements}

These tasks and requirements include: 
- Review test plan with grinder manufacturer

- Obtain feedstock for grinding test

- Define material characterization grinding tests

\subsubsection{Review Test Plan with Grinder Manufacturer}

INL project team leaders will convene meetings with grinder equipment manufacturers to define their role in the test plan and to ascertain their commitment to the test. At this time, the arrangements will be made to conduct a pre-test evaluation or material characterization test at the grinder manufacturer's site to grind several bales of various feedstocks with different screen sizes. The feedstock varieties include: corn stover, wheat straw, switch grass, miscanthus grass, rice straw, and sorghum stover. The bales need to be typical 4'x4'x8' square bales weighing about 1000 pounds each (weight varying with feedstock variety and moisture content). The number of screens and screen sizes will be determined by the grinder manufacturers. However, three screens are being proposed as a starting point for discussion. The INL will issue a subcontract with the grinder manufacturer under a 50/50 cost share agreement. The INL and the grinder manufacturer may also enter into a Cooperative Research and Development Agreement (CRADA) to protect proprietary information if the work performed under the subcontract warrants addition research. The tasks, performers, and deliverables of this section are listed in the following table.

Table 1. Section 4.1.1 general tasks, performers and deliverables

\begin{tabular}{|l|l|l|l|}
\hline \multicolumn{1}{|c|}{ Tasks } & \multicolumn{1}{|c|}{ Performer } & \multicolumn{1}{c|}{ Deliverable } & \multicolumn{1}{c|}{ Notes } \\
\hline $\begin{array}{l}\text { Meet with grinder } \\
\text { manufacturer to } \\
\text { review test plan. }\end{array}$ & $\begin{array}{l}\text { INL and } \\
\text { Grinder Mfg. }\end{array}$ & $\begin{array}{l}\text { Agreement on roles } \\
\text { and responsibilities } \\
\text { of teams }\end{array}$ & Make adjustments in test plan as required. \\
\hline $\begin{array}{l}\text { Initiate subcontract } \\
\text { and CRADA if } \\
\text { warranted and } \\
\text { desired }\end{array}$ & $\begin{array}{l}\text { INL and } \\
\text { Grinder Mfg. }\end{array}$ & $\begin{array}{l}\text { Subcontract and } \\
\text { CRADA documents }\end{array}$ & $\begin{array}{l}\text { Documents generated by INL and signed by } \\
\text { Grinder Mfg. This agreement details the cost } \\
\text { sharing and the roles and responsibilities of the } \\
\text { partners. }\end{array}$ \\
\hline $\begin{array}{l}\text { Scheduled grinder for } \\
\text { characterization test. }\end{array}$ & $\begin{array}{l}\text { INL and } \\
\text { Grinder Mfg. }\end{array}$ & Scheduled grinder. & $\begin{array}{l}\text { The material characterization test is designed to } \\
\text { give the grinder one week to mobilize, grind } \\
\text { and demobilize. Ensure they have staging } \\
\text { space. }\end{array}$ \\
\hline
\end{tabular}

\subsubsection{Obtain Feedstock for Grinding Test}

The feedstock choices for the grinding tests include: corn stover, wheat straw, switch grass, miscanthus grass, rice straw, and sorghum stover, but these may change depending on availability at the test time. Approximately three bales of each feedstock will be preprocessed for each screen size. Additional bales of each feedstock will be furnished to the grinder manufacturer to prepare for the material characterization test if they request them. The feedstock will be staged at the grinder manufacturer's site prior to testing. The tasks, performers, and deliverables of this section are listed in the following table. 
Table 2. Section 4.1.2 general tasks, performers and deliverables

\begin{tabular}{|c|c|c|c|}
\hline Tasks & Performer & Deliverable & Notes \\
\hline $\begin{array}{l}\text { Order } 9 \text { bales of each } \\
\text { of the six feedstock } \\
\text { varieties for each of } \\
\text { the grinder } \\
\text { manufacturer tests. }\end{array}$ & INL & $\begin{array}{l}54 \text { total bales of } \\
\text { feedstock material for } \\
\text { each of the grinder } \\
\text { manufacturer tests. }\end{array}$ & $\begin{array}{l}\text { The feedstock varieties include: corn stover, } \\
\text { wheat straw, switch grass, miscanthus grass, } \\
\text { rice straw, and sorghum stover. }\end{array}$ \\
\hline $\begin{array}{l}\text { Order additional } \\
\text { bales }(5) \text { of each } \\
\text { feedstock variety }\end{array}$ & INL & $\begin{array}{l}30 \text { additional bales } \\
\text { for the grinder } \\
\text { manufacture to } \\
\text { prepare for the } \\
\text { material } \\
\text { characterization test. }\end{array}$ & $\begin{array}{l}\text { These bales allow the grinder manufacturer to } \\
\text { practice and to fine-tune their machine before } \\
\text { the test. }\end{array}$ \\
\hline $\begin{array}{l}\text { Deliver all bales to } \\
\text { the grinder } \\
\text { manufacturer site. }\end{array}$ & $\begin{array}{l}\text { Trucking } \\
\text { contractor }\end{array}$ & $\begin{array}{l}\text { Bales on site before } \\
\text { the material } \\
\text { characterization test. }\end{array}$ & $\begin{array}{l}\text { The grinder manufacturer will need to provide a } \\
\text { staging site with good drainage that will allow } \\
\text { the feedstock material to sit from } 2-4 \text { weeks. }\end{array}$ \\
\hline $\begin{array}{l}\text { Unload and stage } \\
\text { bales. }\end{array}$ & $\begin{array}{l}\text { Trucking } \\
\text { contractor and } \\
\text { Grinder Mfg }\end{array}$ & $\begin{array}{l}\text { Bales staged for the } \\
\text { material } \\
\text { characterization test. }\end{array}$ & \\
\hline Cover the bales & Grinder Mfg & $\begin{array}{l}\text { Bales protected from } \\
\text { weather }\end{array}$ & Bales may need to be covered. \\
\hline
\end{tabular}

\subsubsection{Define Material Characterization Grinding Tests}

The material characterization grinding tests are designed to 1) introduce the grinder manufacturer to materials they may not have ground before, 2) characterize the nuances/aspects/attributes of their grinding machine for each feedstock variety, and 3) grind different biomass feedstocks with different screen sizes to determine or define the fractionation characteristics of the grinder as they affect the bulk density, particle size distribution, and quality of the size reduced biomass, and 4) select an optimum screen size for the Machine Characterization Test (section 5.0) based on different feedstock varieties. The tasks, performers, and deliverables of this section are listed in the following table.

Table 3. Section 4.1.3 general tasks, performers and deliverables

\begin{tabular}{|l|l|l|l|}
\hline \multicolumn{1}{|c|}{ Tasks } & \multicolumn{1}{|c|}{ Performer } & \multicolumn{1}{c|}{ Deliverable } & \multicolumn{1}{c|}{ Notes } \\
\hline $\begin{array}{l}\text { Conduct practice } \\
\text { grinding }\end{array}$ & Grinder Mfg & $\begin{array}{l}\text { Prepared Grinder } \\
\text { Mfg. }\end{array}$ & $\begin{array}{l}\text { The grinder manufacturer may need to prepare } \\
\text { for the test. }\end{array}$ \\
\hline $\begin{array}{l}\text { Identify/evaluate } \\
\text { grinder } \\
\text { configurations. }\end{array}$ & INL & $\begin{array}{l}\text { Assessment of } \\
\text { grinder configuration } \\
\text { for testing }\end{array}$ & $\begin{array}{l}\text { Assess the grinder manufacturers' models, } \\
\text { configurations, and engineering support for full- } \\
\text { scale testing. }\end{array}$ \\
\hline $\begin{array}{l}\text { Grind 3 bales each of } \\
\text { corn stover, wheat } \\
\text { straw, switch grass, } \\
\text { miscanthus grass, rice } \\
\text { straw, and sorghum } \\
\text { stover, with up to } \\
\text { four screen sizes }\end{array}$ & $\begin{array}{l}\text { INL and } \\
\text { Grinder Mfg }\end{array}$ & $\begin{array}{l}\text { Ground corn stover, } \\
\text { wheat straw, switch } \\
\text { grass, miscanthus } \\
\text { grass, rice straw, and } \\
\text { sorghum stover }\end{array}$ & $\begin{array}{l}\text { The four screen sizes include: 0.25-inch, 1.5- } \\
\text { inch, 3.0-inch, and 6.0-inch. For this step, the } \\
\text { screens need to be changed three times. } \\
\text { Feedstock bales need to be loaded four separate } \\
\text { times and the excess ground material needs to } \\
\text { be removed as needed. }\end{array}$ \\
\hline
\end{tabular}




\begin{tabular}{|l|l|l|l|}
\hline $\begin{array}{l}\text { Collect grind material } \\
\text { samples on each } \\
\text { feedstock variety and } \\
\text { screen size. }\end{array}$ & $\begin{array}{l}\text { INL and } \\
\text { Grinder Mfg }\end{array}$ & $\begin{array}{l}\text { Captured samples for } \\
\text { each feedstock } \\
\text { variety and screen } \\
\text { size }\end{array}$ & $\begin{array}{l}\text { Collect samples using 5 gallon sized plastic } \\
\text { buckets and sample bags (2-gallon Ziploc type) } \\
\text { as needed. }\end{array}$ \\
\hline Package samples & INL & $\begin{array}{l}\text { Samples packaged } \\
\text { for shipment }\end{array}$ & $\begin{array}{l}\text { Put samples in plastic buckets or shipping } \\
\text { boxes. }\end{array}$ \\
\hline Ship samples & INL & Samples shipped & $\begin{array}{l}\text { Need to ship the samples to the INL for } \\
\text { analysis. }\end{array}$ \\
\hline $\begin{array}{l}\text { Dispose of ground } \\
\text { material. }\end{array}$ & $\begin{array}{l}\text { INL and } \\
\text { Grinder Mfg }\end{array}$ & Disposed material. & $\begin{array}{l}\text { Need to ensure adequate and correct disposal of } \\
\text { excess ground material from the test. }\end{array}$ \\
\hline $\begin{array}{l}\text { Capture lessons } \\
\text { learned from the } \\
\text { grinding test. }\end{array}$ & $\begin{array}{l}\text { INL and } \\
\text { Grinder Mfg }\end{array}$ & $\begin{array}{l}\text { Lessons learned } \\
\text { captured. }\end{array}$ & $\begin{array}{l}\text { Meet with team members after the tests and } \\
\text { discuss potential test plan changes. }\end{array}$ \\
\hline $\begin{array}{l}\text { Evaluate draft test } \\
\text { procedures }\end{array}$ & $\begin{array}{l}\text { INL and } \\
\text { Grinder Mfg }\end{array}$ & $\begin{array}{l}\text { Evaluated test } \\
\text { procedures }\end{array}$ & Revise the test procedures. \\
\hline $\begin{array}{l}\text { Update the INL test } \\
\text { plan and test } \\
\text { procedures. }\end{array}$ & INL & $\begin{array}{l}\text { Updated procedures } \\
\text { and test plan }\end{array}$ & Incorporate comments and finalize test plan. \\
\hline
\end{tabular}

\subsection{Grind Feedstock}

The material characterization test tasks and requirements were explained in section 4.1.1. Two major efforts of this test are to:

- Obtain grinding data

- Capture ground material samples

The analysis of the data and samples will characterize the deconstruction profile and bulk properties of the ground feedstocks and define the optimum screen size (target particle size) for the subsequent Machine Characterization Test.

\subsubsection{Obtain Grinding Data}

All grinding data and sample material logistics from the Material Characterization Test are captured in logbooks and with photographs.

\subsubsection{Logbooks}

Custom logbooks will be prepared and bound with pages of prepared tables to capture data relevant to the test. For general test notations and narratives, standard commercially available logbooks will be used. The test data includes all information related to the feedstock varieties, bales, grinding equipment, operational information, and environment/weather. The logbooks represent the permanent record and tangible link of the data to a bale number or to a sample number. The information in the logbooks will supplement and support the researchers when the samples are analyzed in the laboratory. The logbooks become the permanent record of all raw data. For this testing several logbooks are required:

- Field team leader narrative logbook 
- Feedstock material data logbook

- Equipment/hardware logbook

- Sample Logbook

\subsubsection{Field Team Leader Narrative Logbook}

The INL field team leader will hand-write the day-to-day history of the field work in a lined bound narrative logbook. The hand-written text will contain a general narrative of the field work, special or unusual events, names and points of contacts of all team members, and dates. Also, the INL leader will make notations on weather conditions, including temperature, humidity, and wind speed, during the tests. This logbook is a standard commercially bound laboratory book with lines on numbered pages.

\subsubsection{Feedstock Materials Data Logbook}

The Feedstock Materials Data Logbook will be used to record and document information pertaining to feedstock material. This logbook is a custom made book with pages of single sided tables/charts that track and document feedstock material data: history, origin, varieties, bales shapes, etc. One page in the logbook shows the bale pedigree. Examples of the headings of this page are shown in Figure 4.

\begin{tabular}{|c|c|c|c|c|c|}
\hline Feedstock & Variety & Bale Shape & $\begin{array}{c}\text { Number of } \\
\text { Bales }\end{array}$ & $\begin{array}{c}\text { County/State } \\
\text { Grown }\end{array}$ & Year Harvested \\
\hline Corn Stover & Pioneer & Square & 3 & Stafford/Kansas & 2006 \\
\hline
\end{tabular}

Figure 4. An example of bale pedigree

A legend of the column headings and their definitions are listed below:

- Feedstock: Identify the feedstock, i.e.: corn stover

- Variety: Need to know the commercial variety name

- Bale Shape: Either round or square

- Number of Bales: This is the total number of bales for this feedstock variety and type.

- County and State Grown: Identify the location (county/state) where the feedstock variety and type was grown.

- Year Harvested: Need to know the year the feedstock was harvested.

\subsubsection{Equipment/Hardware Logbook}

This logbook will be used to record grinding equipment specifications and performance, and to record all other pertinent information about the equipment being tested. This would include items such as engine type, engine horsepower, make and model of the grinder, hammer or fixed cutter type, drum diameter, conveyor length and width, etc. An example of the logbook page and headings is shown in Figure 5. 


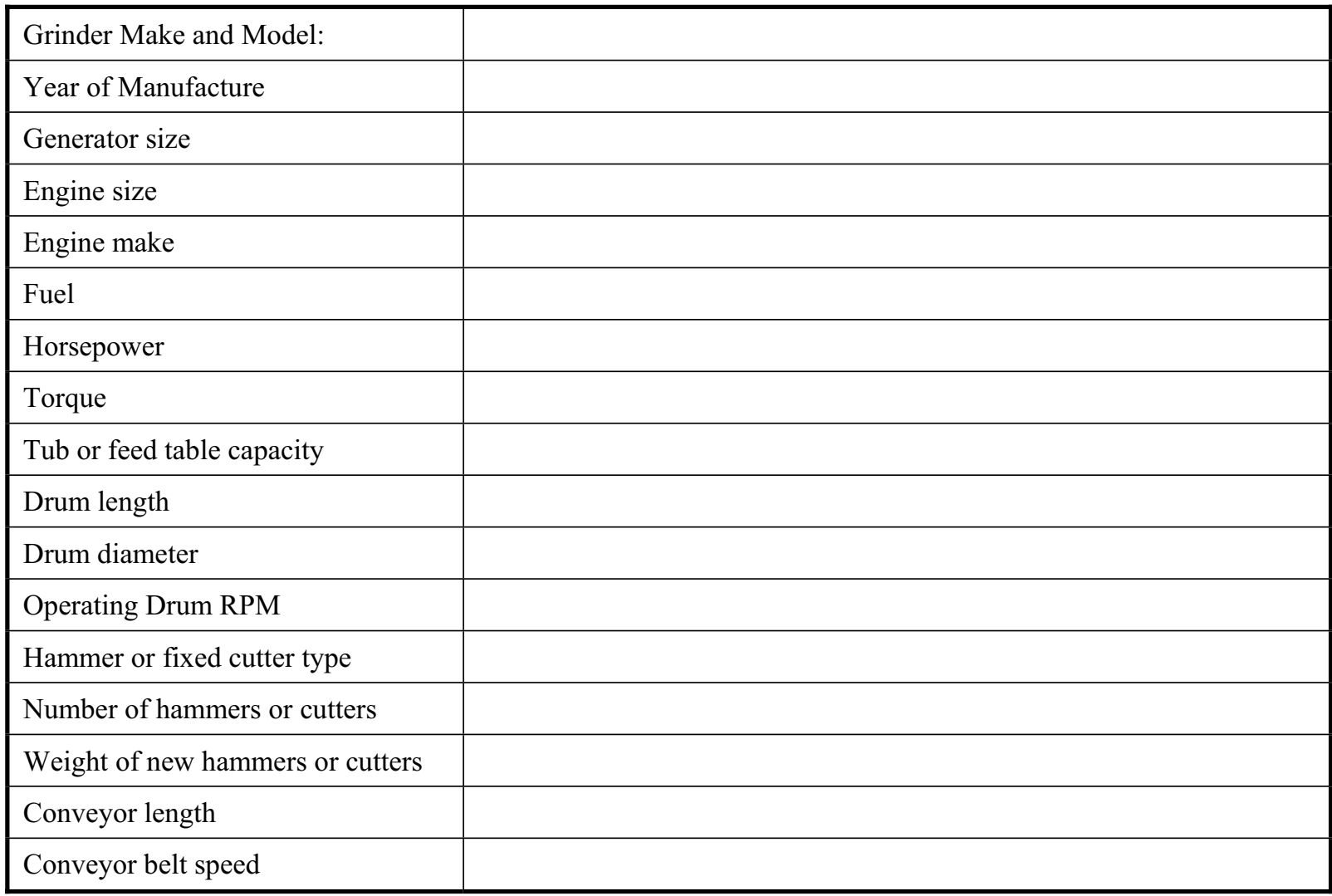

Figure 5. An example of Equipment/Hardware Logbook data page.

\subsubsection{Sample Logbook}

The Sample Logbook will contain the tracking records for all feedstock samples collected for later laboratory analysis. Figure 6 shows an example of this page.

\begin{tabular}{|l|c|c|c|c|c|c|c|c|}
\hline \multicolumn{2}{|l|}{ Sample Date } & \multicolumn{2}{l|}{$7 / 17 / 2007$} \\
\hline \multicolumn{2}{|l|}{ Sample Time } & \multicolumn{2}{l|}{$13: 45$} \\
\hline Grinder & "Manufacturer name and model number" \\
\hline $\begin{array}{c}\text { Sample } \\
\text { Number }\end{array}$ & $\begin{array}{c}\text { Sample } \\
\text { Material }\end{array}$ & $\begin{array}{c}\text { Sample } \\
\text { Moisture } \\
\mathbf{( \% )}\end{array}$ & $\begin{array}{c}\text { Screen } \\
\text { Size }\end{array}$ & $\begin{array}{c}\text { Opening } \\
\text { Shape }\end{array}$ & $\begin{array}{c}\text { Sample } \\
\text { Container }\end{array}$ & $\begin{array}{c}\text { Sample } \\
\text { Type }\end{array}$ & $\begin{array}{c}\text { Sample } \\
\text { Location }\end{array}$ & Notes \\
\hline 03 & $\begin{array}{c}\text { Corn } \\
\text { Stover }\end{array}$ & $15 \%$ & 3 -inch & Square & $\begin{array}{c}\text { 5-gal } \\
\text { bucket }\end{array}$ & Grab & $\begin{array}{c}\text { End of } \\
\text { chute }\end{array}$ & $\begin{array}{c}\text { Last } \\
\text { sample of } \\
\text { grind }\end{array}$ \\
\hline
\end{tabular}

Figure 6. An example page of the Sample Logbook.

A legend of the column headings and their definitions are listed below:

- Sample Date: All dates will be recorded as mm/dd/yyyy.

- Sample Time: Recorded military time of test i.e. 8:00 AM is 8:00, but 8:00 PM is 20:00.

- Grinder: Name of the grinder manufacturer and model number. 
- Sample Number: The sample number will be a unique number or identifier. The number will be used to track and link samples to feedstock types and varieties.

- Sample Material: The feedstock variety.

- Sample Moisture: This is the percent moisture of the sample material.

- Screen Size: The screen is sized with openings to allow a certain size fraction to be processed during the grinding operation. With small screen, the finer the size fraction will be, but with smaller openings, longer grinding times are required to get the small sizes. The measurement of the screen size will be recorded.

- Opening Shape: Screen opening shapes can be variations of round (oval), square (rectangular), or other geometric shapes that can be cut or machined into the thick steel screens. The screen opening shape adds a degree of variation to the filtering or sieving of the size fraction through the screen to meet the needs of the end user. The screen opening shape will be recorded.

- Sample Container: Enter the sample container type (i.e.: 2-gallon Ziploc type bag, 5-gallon plastic bucket or super sack).

- Sample Type: The sample type is descriptive to the sample taken: bucket, bag, sack, or core sample. The sample type will be listed.

- Sample Location: The sample location will be recorded. The location is a descriptive to where the sample is taken: mid-stream, middle, edge or random, etc.

- Notes: Notes are any additional notations or information required to add clarity to the reader.

\subsubsection{Photographs}

Digital cameras will be available to take photographs and video clips of all aspects of the grinding operation. This includes the bale handling, screen changing, discharge of ground material, sampling, etc.

\subsubsection{Capture Material Grind Samples}

Capturing samples is a composite of several related sub-activities. These include:

- Operational safety meeting

- Sample containers

- Sample collection

- Sample container labels

- $\quad$ Shipping

\subsubsection{Operational Safety Meeting}

Prior to starting the grinding operation and taking of samples, a meeting of all on-site project personnel will discuss in an organized training session any operational, safety and sample taking issues to ensure the tests and associated sampling can be performed adequately and in a safe manner. Part of the discussion will include the appropriate personal protective equipment: eye protection, hearing protection, 
hard hats, etc. A summary of the meeting, the material covered and a list of the attendees will be recorded in the Field Team Leaders Narrative Logbook

\subsubsection{Sample Containers}

The sample containers need to be staged at the test location prior to the Material Characterization Test. The sample containers for this project include:

- 30 Gallon Drums: Plastic 30 gallon drums will hold the ground material from each grinding set. These plastic drums will also double as shipping containers.

- Five-gallon Buckets: Plastic buckets with sealable lids and bail handles will be used to collect a number of samples during the grinding tests. These buckets also double as shipping containers.

- Bags: Two-gallon Ziploc type bags are used for smaller samples in the grinding tests. These bags can be placed into buckets, boxes or coolers for shipping.

For the Material Characterization Test, super sacks may not be required or used.

\subsubsection{Sample Collection}

Two sample sets will be taken. Before the Material Characterization test begins, a five-gallon bucket sample of each feedstock variety will be taken from a parent bale before it is ground, and at least two bucket samples will be taken during the grinding operation of each feedstock variety and screen size.

Previous INL tests of an industrial hammer mill grinder resulted in estimated grinding rates of 25-30tons per hour, grinding wheat and barley straw. At this assumed rate for the Material Characterization tests, and with three 1000-pound bale pre-loaded, the total grind time of three bales could be 180 -seconds. The 5-gallon bucket samples will be taken mid-stream as the ground material is expelled from the discharge chute or conveyer. The technician will stand near the discharge area and maneuver a sample bucket into the flow of ground material to fill the bucket. Since a minimum of two bucket samples are required, the technician will have buckets staged nearby and work quickly to capture two bucket samples in 180-seconds. To ensure the chain of custody between the sample and the container is not lost, identical (duplicate) labels for each bucket will be attached on both the inside and outside of the container before capturing the samples. The technician will be wearing the appropriate personal protective equipment during the capturing of the samples: eye protection, hearing protection, hard hat, etc. Bag samples may also be captured as needed. These samples should be capture directly if possible, but may be loaded from a bucket if proper sampling procedures are followed. As samples are captured, they are to be issued a number and that number with the feedstock data will be entered into the Sample Logbook.

\subsubsection{Sample Container Labels}

For sample management and tracking purposes, pre-printed sample labels will be used. The sample labels are printed on a 3.3 X 4-inch Avery Shipping Label, No. 6464. Figure 7 shows the proposed sack/bucket/bag sample identification label. 


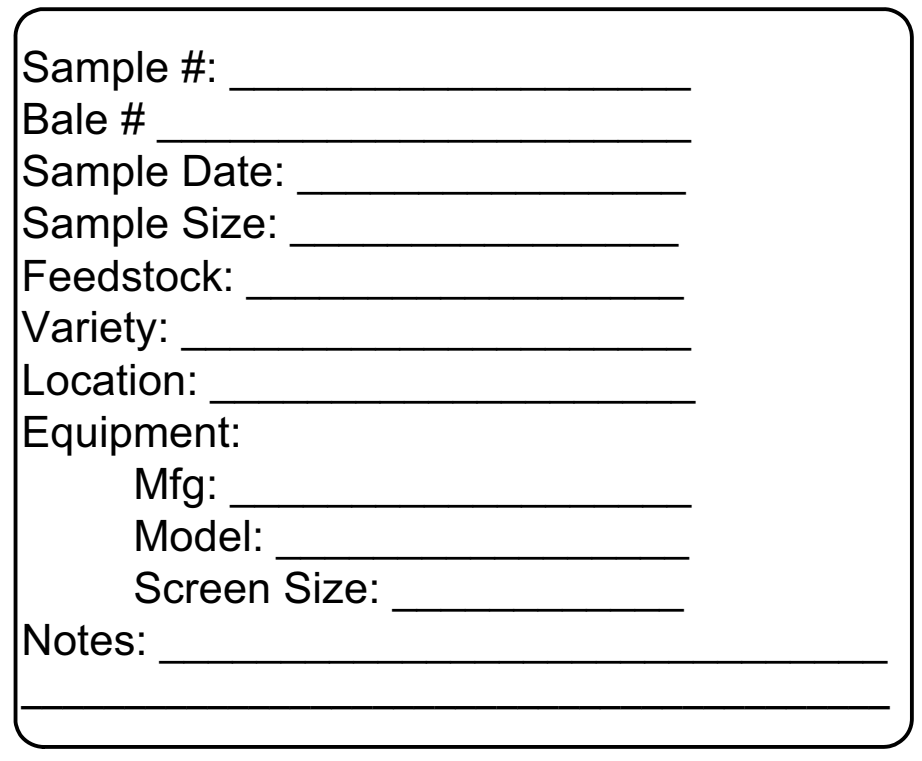

Figure 7. An example of sample container label

\subsubsection{Shipping}

Plastic buckets make excellent shipping containers for feedstock material. They are inexpensive, readily available, sturdy, and double as both the sample and shipping container. Multiple 2-gallon bag samples can be placed into a bucket, cardboard box or polyethylene cooler for shipping. Packing tape will be liberally used to wrap around the lid and bucket to ensure the lid does not separate during shipment. Buckets will be shipped directly to the INL using FedEx pre-paid shipping labels to greatly aid in the shipping process. Super sack samples, if required, will be shipped to an INL feedstock storage site in Terreton, Idaho.

\subsubsection{Conduct Screen Size Determination}

Grinding information collected during the Material Characterization Tests characterizes a number of physical properties of the feedstock and will help define the optimum grinding screen for various feedstocks preparatory to the Machine Characterization Test. Screen size determination will be largely performed by the grinder manufacturer based on analysis of post-test data collected during the Material Characterization Tests performed by both the INL and the grinder manufacturer. The selection of an optimal screen size and shape for the Machine Characterization Test is necessary to reduce the research variables used to characterize the performance of the grinder during the Machine Characterization Test.

\section{MACHINE CHARACTERIZATION TEST}

The tasks and activities of the Machine Characterization Test include:

- Define tasks and requirements

- $\quad$ Grind feedstock

- Obtain grinding data

- Obtain material grind samples 


\subsection{Define Tasks and Requirements}

The Machine Characterization Test will grind a variety of feedstocks at various moistures using one screen configuration as determined from the Material Characterization Test. The proposed feedstock varieties include: corn stover, wheat straw, sorghum stover, switch grass and soybean straw, but may change as the time to harvest approaches. This test will grind approximately 30 tons of baled feedstock (a grinding set) for each variety and moisture. It is estimated that each grinding set ( $\sim 30$ tons) will take about one hour.

Subject matter experts on grinding feedstock say that moisture content is a major variable affecting grinding times of feedstock; therefore to assess the grinding efficiency, the feedstock types will be procured with different moisture contents. Since moisture content is directly related to harvest time, the moistures will be selected at a later time. Also, some moisture values can be maintained with bale wrapping at harvest time, and through individual moisture testing, the bales of like moisture may be segregated prior to grinding. The actual feedstock moisture values are not known at this time; therefore the moistures values are hereafter defined as moisture 1 , moisture 2 , and moisture 3 . The initial feedstock varieties and moistures (subject to change) include:

- Corn stover with three moisture levels (moisture 1, 2 and 3), 30 tons for each moisture level.

- Wheat straw with two moisture levels (moisture 1 and 2), 30 tons for each moisture level.

- Sorghum stover with three moisture (moisture 1,2 and 3), 30 tons for each moisture level.

- Switch grass with two moisture levels (moisture 1 and 2), 30 tons for each moisture level.

- Soybean straw with two moisture levels (moisture 1 and 2), 30 tons for each moisture level.

The goals of these grinding tests are to capture enough data through machine performance parameters and material sample analysis to:

- Generally assess commercially available hammer and fixed cutter grinder technologies

- Establish a capacity measurement in unit of ton/hour $/ \mathrm{kW}$

- Establish an operational efficiency

- Measure a grinding variability of feedstock varieties

- Measure a grinding variability of feedstock moistures

- Conduct a sensitivity analysis of feedstock varieties to operating parameters

- Further define a total grinding, hauling, and handling cost to preprocess feedstocks

This machine characterization test has four main tasks bulleted below:

- Grind the feedstocks

- Conduct a safety meeting

- Grind 30 tons of each feedstock variety at the above stated moistures

- Collect the mechanical/environmental test data 
- Measure temperature and moisture of bales

- Weight of each bale immediately prior to grinding

- Record wind speed, humidity and temperature for each grinding set

- Record total bale grinding time for each grinding set

- Measure temperature of ground material

- Record trailer load time

- Record tractor-trailer tare and net weight

- Record trailer un-loading time

- Quantify losses

- Record fuel consumption, torque, drum RPM and equipment temperatures on grinders

- Capture ground material samples

- Capture airborne particulate samples

- Take samples from vacuum collector system

- Capture super sack, or equivalent container, sample(s)

- Stop truck loading when last bale of a grinding set is loaded

- Move truck when last bale is loaded

- Use forklift to support and hold the sack

- Fill sack(s) with last ground material from last bale.

- Capture laboratory sample(s)

- Ship ground material samples to INL

\subsubsection{Tasks, Performers, and Deliverables}

Details relating to the tasks, performers, and deliverables for this test are listed in the following table.

Table 4. Section 5.1.1 general tasks, performers and deliverables

\begin{tabular}{|l|l|l|l|}
\hline \multicolumn{1}{|c|}{ Tasks } & \multicolumn{1}{|c|}{ Performer } & \multicolumn{1}{c|}{ Deliverable } & \multicolumn{1}{c|}{ Notes } \\
\hline $\begin{array}{l}\text { Conduct Operational } \\
\text { safety meeting }\end{array}$ & $\begin{array}{l}\text { Entire Field } \\
\text { Team }\end{array}$ & Operational training & $\begin{array}{l}\text { This training, conducted by the grinder } \\
\text { manufacture, will be relevant to the operation of } \\
\text { the grinder and loading equipment. Other } \\
\text { hazards such as fire, noise, and dust will also be } \\
\text { addressed. Personal Protection Equipment } \\
\text { (PPE) will be provided as needed. }\end{array}$ \\
\hline $\begin{array}{l}\text { Grind } 30 \text { tons }(\sim 60 \\
\text { bales) of corn stover } \\
\text { at moisture 1 }\end{array}$ & $\begin{array}{l}\text { Loader } \\
\text { operator and } \\
\text { grinder team }\end{array}$ & $\begin{array}{l}30 \text { tons of corn } \\
\text { stover ground } \\
\text { material }\end{array}$ & $\begin{array}{l}\text { Loader operator will keep a continuous supply of } \\
\text { feedstock in the grinder to ensure the grinder is } \\
\text { working at maximum capacity }\end{array}$ \\
\hline
\end{tabular}




\begin{tabular}{|l|l|l|l|}
\hline $\begin{array}{l}\text { Capture test data and } \\
\text { samples }\end{array}$ & INL & $\begin{array}{l}\text { Test data and } \\
\text { samples captured }\end{array}$ & $\begin{array}{l}\text { Test data is captured before and throughout the } \\
\text { grinding operation with data loggers, logbooks, } \\
\text { and notes on personal observations. All test data } \\
\text { and samples captured per sampling plan. }\end{array}$ \\
\hline NOTE: The previous two rows will be repeated for all of the various feedstock types and moisture contents. \\
\hline $\begin{array}{l}\text { Ship material } \\
\text { samples }\end{array}$ & INL & Samples shipped & Ship samples to Idaho Falls and Terreton, ID \\
\hline $\begin{array}{l}\text { Dispose of excess } \\
\text { ground material }\end{array}$ & $\begin{array}{l}\text { INL and } \\
\text { trucking } \\
\text { contractor }\end{array}$ & Material disposed & $\begin{array}{l}\text { This may be at a land fill or other location. } \\
\text { Need to ensure this does not negatively impact } \\
\text { other commercial feed grinding operations. }\end{array}$ \\
\hline $\begin{array}{l}\text { Load ground } \\
\text { feedstock in truck } \\
\text { for Biorefinery }\end{array}$ & $\begin{array}{l}\text { INL and } \\
\text { trucking } \\
\text { contractor }\end{array}$ & $\begin{array}{l}\text { Biorefinery material } \\
\text { loaded }\end{array}$ & $\begin{array}{l}\text { Ascertain type and volume of ground feedstock } \\
\text { to be shipped to Biorefinery. }\end{array}$ \\
\hline $\begin{array}{l}\text { Ship samples to } \\
\text { Biorefinery }\end{array}$ & $\begin{array}{l}\text { INL and } \\
\text { trucking } \\
\text { contractor }\end{array}$ & $\begin{array}{l}\text { Biorefinery material } \\
\text { shipped }\end{array}$ & Deliver ground material to Biorefinery \\
\hline $\begin{array}{l}\text { Demobilize } \\
\text { equipment }\end{array}$ & Grinder team & $\begin{array}{l}\text { Equipment removed } \\
\text { and site cleaned up }\end{array}$ & $\begin{array}{l}\text { The test is scheduled to take one week including } \\
\text { mobilization and demobilization of the grinder. }\end{array}$ \\
\hline
\end{tabular}

\subsubsection{Requirements and Needs}

The machine characterization test resource requirements and needs are shown in Figure 8.

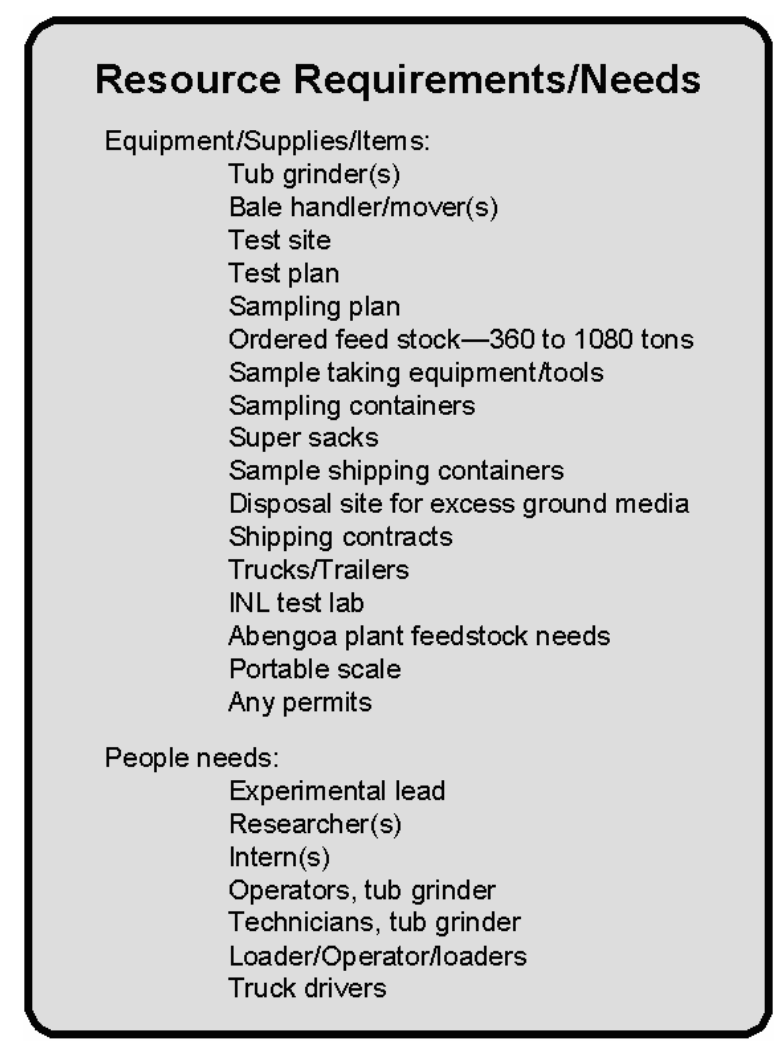

Figure 8. Machine characterization test resource requirements and needs 


\subsubsection{Set-up for Machine Characterization Test}

Details related to the tasks, performers, and deliverables of this section are listed in Table 5.

Table 5. Section 5.1.3 general tasks, performers and deliverables

\begin{tabular}{|c|c|c|c|}
\hline Tasks & Performer & Deliverable & Notes \\
\hline Secure test site & $\begin{array}{l}\text { INL and other } \\
\text { test partners. }\end{array}$ & $\begin{array}{l}\text { Test site secured for } \\
\text { a test. }\end{array}$ & $\begin{array}{l}\text { The site needs to be large enough to stage the } \\
\text { equipment of the grinding, handling, sampling } \\
\text { and disposal activities. Establish cost sharing } \\
\text { and etc. }\end{array}$ \\
\hline $\begin{array}{l}\text { Ensure testing is } \\
\text { allowed }\end{array}$ & INL & $\begin{array}{l}\text { An email from the } \\
\text { site owner that this } \\
\text { work is allowed. }\end{array}$ & $\begin{array}{l}\text { This may include checking with local authorities } \\
\text { and agencies to ensure this test is permitted-- } \\
\text { fire department, police, landfill (material } \\
\text { disposal), and environmental quality. }\end{array}$ \\
\hline Order feedstock & INL & Order for feedstock & $\begin{array}{l}\text { This order is for } 30 \text {-tons each of corn stover, } \\
\text { wheat straw, sorghum stover, switch grass and } \\
\text { soybean straw, with a variety of moistures for } \\
\text { each feedstock. Approximately } 360 \text { tons of } \\
\text { feedstock will be needed. The feedstock } \\
\text { varieties and moistures may change closer to } \\
\text { harvest time. }\end{array}$ \\
\hline Deliver feedstock & $\begin{array}{l}\text { Trucking } \\
\text { contractor }\end{array}$ & $\begin{array}{l}\text { Feedstock delivered } \\
\text { to test site }\end{array}$ & Deliver about 720 bales of feedstock to test site. \\
\hline $\begin{array}{l}\text { Develop feedstock } \\
\text { stacking plan }\end{array}$ & INL & $\begin{array}{l}\text { Written stacking } \\
\text { plan }\end{array}$ & $\begin{array}{l}\text { Need to develop a feedstock stacking plan for } \\
\text { the bales to provide ready access to the bales. }\end{array}$ \\
\hline $\begin{array}{l}\text { Stage/stacked } \\
\text { feedstock }\end{array}$ & INL & $\begin{array}{l}\text { Staged/stacked } \\
\text { feedstock }\end{array}$ & $\begin{array}{l}\text { Feedstock bales will be stacked for ready access } \\
\text { to the bales. }\end{array}$ \\
\hline Identify/label bales & INL & Bales marked & $\begin{array}{l}\text { Unique numbers are needed on each bale for } \\
\text { tracking purposes. Number scheme is to be } \\
\text { determined by INL. }\end{array}$ \\
\hline Core selected bales & INL & Core samples taken & $\begin{array}{l}\text { The core samples are required for the analysis of } \\
\text { the feedstock. INL will selectively core bales } \\
\text { and collect samples for quality, moisture, etc. }\end{array}$ \\
\hline $\begin{array}{l}\text { Obtain feedstock } \\
\text { weights }\end{array}$ & Sensotech & $\begin{array}{l}\text { Weights of } \\
\text { feedstock }\end{array}$ & $\begin{array}{l}\text { Bale weight sensors at the time of harvest will be } \\
\text { used to obtain all bale weights. }\end{array}$ \\
\hline $\begin{array}{l}\text { Contract for } \\
\text { equipment to haul } \\
\text { ground feedstock } \\
\text { material. }\end{array}$ & INL & Truck contracts & $\begin{array}{l}\text { A contract for both equipment and operators to } \\
\text { haul ground material to a biorefinery or landfill. } \\
\text { The trailer will be a } 53 \text {-foot with a live belt for } \\
\text { discharge. Need two trucks and two operators. }\end{array}$ \\
\hline Weigh tractor/trailer & $\begin{array}{l}\text { Trucking } \\
\text { operator }\end{array}$ & $\begin{array}{l}\text { Tare weight of } \\
\text { tractor/trailer }\end{array}$ & $\begin{array}{l}\text { Conduct weigh-in (tare weight) of trucks and } \\
\text { trailers with full tanks of fuel. Tare weight are } \\
\text { to be repeated after dumping each load and prior } \\
\text { to a receiving a new load. }\end{array}$ \\
\hline $\begin{array}{l}\text { Obtain bale handling } \\
\text { equipment }\end{array}$ & INL & $\begin{array}{l}\text { Bale handling } \\
\text { equipment secured }\end{array}$ & $\begin{array}{l}\text { Two telehandler machines are needed. Each } \\
\text { machine should come with a dedicated operator }\end{array}$ \\
\hline Set up grinder & Grinder Mfg & Grinder at site & $\begin{array}{l}\text { The material characterization test should only } \\
\text { take two days, but one week is planned for. }\end{array}$ \\
\hline
\end{tabular}


Table 5. (cont.)

\begin{tabular}{|l|l|l|l|}
\hline $\begin{array}{l}\text { Ensure availability } \\
\text { of grinder personnel, } \\
\text { spare parts, and } \\
\text { maintenance } \\
\text { vehicles. }\end{array}$ & Grinder Mfg & $\begin{array}{l}\text { Crews, spare parts } \\
\text { and service trucks at } \\
\text { site. }\end{array}$ & $\begin{array}{l}\text { The grinder manufacturer is required to } \\
\text { adequately staff themselves for the test to service } \\
\text { their machinery. }\end{array}$ \\
\hline $\begin{array}{l}\text { Stage the INL } \\
\text { mobile test trailer }\end{array}$ & INL & $\begin{array}{l}\text { Test trailer is } \\
\text { operational at site }\end{array}$ & $\begin{array}{l}\text { This includes transporting the trailer from the } \\
\text { INL to the test site, setting up the trailer and } \\
\text { ensuring it is powered/wired. }\end{array}$ \\
\hline $\begin{array}{l}\text { Stage sampling } \\
\text { equipment }\end{array}$ & INL & $\begin{array}{l}\text { Sampling equipment } \\
\text { on site }\end{array}$ & $\begin{array}{l}\text { This includes securing all of the bags, } \\
\text { containers, moisture sensors, etc needed for the } \\
\text { test. }\end{array}$ \\
\hline $\begin{array}{l}\text { Stage adequate staff } \\
\text { INL }\end{array}$ & Staff on site & $\begin{array}{l}\text { This includes senior staff and adequate interns } \\
\text { for data gathering tasks. }\end{array}$ \\
\hline $\begin{array}{l}\text { Dispose of excess } \\
\text { ground material }\end{array}$ & $\begin{array}{l}\text { INL with input } \\
\text { from vendors }\end{array}$ & $\begin{array}{l}\text { Disposal of excess } \\
\text { ground material }\end{array}$ & \multicolumn{2}{|l}{} \\
\hline
\end{tabular}

\subsection{Grind Feedstock}

Two parts of grinding the feedstock include:

- Obtaining feedstock and machine data

- Obtaining material samples

\subsubsection{Obtain Feedstock and Machine Data}

Feedstock and machine data from the Machine Characterization Test are captured and archived using:

- Logbooks

- Photographs

- Moisture/Temperature Probes

- Weighing devices

\subsubsection{Logbook}

Custom logbooks will be prepared and bound with pages of prepared tables to record data relevant to the test. For general test notations, standard commercially available logbooks will be used. The test data includes all information related to the feedstock variety, bales, grinding equipment, operational information, and environment/weather. The logbooks represent the permanent record and tangible link of the data to a bale or sample number. The information in the logbooks will supplement the actual samples when the samples are analyzed in the laboratory. The logbooks become the permanent record of all raw data. For this testing several logbooks are required:

- Field team leader narrative logbook

- Feedstock material data logbook 
- Equipment/hardware logbook

- Sample Logbook

\section{Field Team Leader Narrative Logbook}

The INL field team leader will hand-write the day-to-day history of the field work in lined bound narrative logbook. The hand-written text will contain a general narrative of the field work, special or unusual events, names and points of contacts of all team members, and dates. This notebook will be used to document weather conditions, including temperature, humidity, and wind speed, during the tests. This logbook is a standard commercially bound laboratory book with lines on numbered pages.

\section{Feedstock Materials Data Logbook}

The Feedstock Materials Data Logbook will be used to record and document information pertaining to feedstocks from the various test. This logbook is a custom made book with pages of single sided tables/charts that track and document feedstock material data including, history, origin, varieties, bales shapes, etc. Figure 9 shows an example of a page in the Feedstock Materials Data Logbook.

\begin{tabular}{|c|c|c|c|c|c|c|c|c|}
\hline \multicolumn{2}{|l|}{ Sample Date } & \multicolumn{2}{l|}{$7 / 17 / 2007$} \\
\hline \multicolumn{2}{|l|}{ Sample Time } & \multicolumn{2}{l|}{$13: 45$} \\
\hline \multicolumn{2}{|l|}{ Grinder } & "Manufacturer name and model number" \\
\hline $\begin{array}{c}\text { Bale } \\
\#\end{array}$ & $\begin{array}{c}\text { Sample } \\
\text { Material }\end{array}$ & $\begin{array}{c}\text { Bale } \\
\text { Weight, } \\
\text { pounds }\end{array}$ & $\begin{array}{c}\text { Sample } \\
\text { Type }\end{array}$ & $\begin{array}{c}\text { Bale } \\
\text { Moisture } \\
\text { Pre-grind }\end{array}$ & $\begin{array}{c}\text { Post } \\
\text { Grind } \\
\text { Moisture }\end{array}$ & $\begin{array}{c}\text { Initial Bale } \\
\text { Temp. (F) }\end{array}$ & $\begin{array}{c}\text { Final } \\
\text { Sample } \\
\text { Temp. (F) }\end{array}$ & Notes \\
\hline 001 & $\begin{array}{c}\text { Wheat } \\
\text { straw }\end{array}$ & 988 & Core & $15 \%$ & $8 \%$ & 75 & 75 & \\
\hline 002 & $\begin{array}{c}\text { Wheat } \\
\text { straw }\end{array}$ & 1078 & Bucket & $15 \%$ & $9 \%$ & 75 & 85 & \\
\hline
\end{tabular}

Figure 9. An example page of the Feedstock Materials Data Logbook.

A legend of the column headings and the definitions of the headings are listed below:

- Sample Date: All dates will be recorded as mm/dd/yyyy.

- Sample Time: Recorded military time of sample (8:00 AM is 8:00, but 8:00 PM is 20:00).

- Grinder: Name of the grinder manufacturer and model number.

- Bale Number: A unique bale identification number that is traceable back to a feedstock and its moisture. By tracking the bale number and grinder performance parameters, grinding efficiencies for feedstock's and moistures can be developed.

- Sample Material: This column will be used to identify the sample material by variety such as wheat straw, corn stover, sorghum stover, etc.

- Bale Weight: Record the weight of the bale prior to feeding it into the grinder.

- Sample Type: The sample type is descriptive to the sample taken: bucket, bag, sack, or core sample. The sample type will be listed. 
- Bale Moisture Pre-Grind: This cell will record the moisture content of the bale in \%, prior to feeding it into the hammer or fixed cutter grinder. A hand-held moisture probe will be used to collect this data. The moisture probes will be calibrated per manufacturer and/or industry standards. Calibration data will be maintained in this notebook also.

- Post Grind Moisture: This column will record any moisture measurements taken after the bale has been run through the hammer or fixed cutter grinder. Efforts will be made to correlate the moisture measurement to the bale or bales that went through the grinder.

- Initial Bale Temperature: Temperature measurements in degrees Fahrenheit will be collected from each bale with a thermal probe, prior to the bale being fed into the grinder. The thermal probe will be calibrated per manufacturer and/or industry standards. Calibration data will also be maintained in this notebook.

- Final Sample Temperature: This column will record temperature measurements of the ground material after it has passed through the grinder. Efforts will be made to correlate this post-grind temperature to the bale or bales that the post grind material originated from.

- Notes: Notes are any additional notations or information required to add clarity to the reader.

\section{Equipment/Hardware Logbook}

This logbook will be used to record information on the grinding equipment specifications and performance. The logbook records all other pertinent information about the equipment being tested. This would include items such as engine type, engine horsepower, make and model of the grinder, hammer or fixed cutter type, hammer or fixed cutter weight before and after the test, drum diameter, conveyor length and width, etc. An example of what the table will look like is shown in Figure 10.

\begin{tabular}{|l|l|}
\hline Grinder Make and Model: & \\
\hline Year of Manufacture & \\
\hline Generator size & \\
\hline Engine size & \\
\hline Engine make & \\
\hline Fuel & \\
\hline Horsepower & \\
\hline Torque & \\
\hline Tub or feed table capacity & \\
\hline Drum length & \\
\hline Drum diameter & \\
\hline Operating Drum RPM & \\
\hline Hammer or fixed cutter type & \\
\hline Number of hammers or cutters & \\
\hline Weight of new hammers or cutters & \\
\hline Conveyor length & \\
\hline
\end{tabular}

Figure 10. An example page of the Equipment/Hardware Logbook. 
Another page in the Equipment/Hardware Logbook records data generated during the grinding of the feedstock. An example of this page is shown in Figure 11.

\begin{tabular}{|c|c|c|c|c|c|c|c|}
\hline \multicolumn{3}{|c|}{ Test Date } & \multicolumn{5}{|l|}{$7 / 17 / 2007$} \\
\hline \multicolumn{3}{|c|}{ Test Start Time (hr:min:sec) } & \multicolumn{5}{|l|}{$13: 45: 10$} \\
\hline \multicolumn{3}{|c|}{ Test End Time (hr:min:sec) } & \multicolumn{5}{|l|}{$14: 12: 36$} \\
\hline \multicolumn{3}{|c|}{ Fuel Use (gal) } & \multicolumn{5}{|l|}{3.1} \\
\hline \multicolumn{3}{|c|}{ Grinder } & \multicolumn{5}{|c|}{ "Manufacturer name and model number" } \\
\hline $\begin{array}{c}\text { Bale } \\
\#\end{array}$ & $\begin{array}{c}\text { Engine } \\
\text { Temp. } \\
\text { (F) }\end{array}$ & $\begin{array}{c}\text { Eng. } \\
\text { Housing } \\
\text { Temp. (F) }\end{array}$ & $\begin{array}{l}\text { Screen Size, } \\
\text { (in) }\end{array}$ & $\begin{array}{c}\text { Opening } \\
\text { Shape }\end{array}$ & $\begin{array}{c}\text { Conveyor } \\
\text { Speed, (fps) }\end{array}$ & $\begin{array}{l}\text { Bale Feed } \\
\text { Time } \\
\text { (hr:min:sec) }\end{array}$ & Notes \\
\hline 021 & 195 & 182 & 1 & Square & 32 & $13: 54: 49$ & \\
\hline 035 & 213 & 185 & 1 & Square & 32 & $14: 02: 04$ & \\
\hline
\end{tabular}

Figure 11. An example of Equipment/Hardware Logbook data page.

A legend of the column headings and the definitions of the headings are listed below:

- Test Date: All dates will be recorded as mm/dd/yyyy.

- Test Start Time: Recorded military start time of test (8:00 AM is 8:00, but 8:00 PM is 20:00).

- Test End Time: Recorded military end time of test (8:00 AM is 8:00, but 8:00 PM is 20:00).

- Fuel Use: The measurement, in gallons, of the fuel being used during 30-ton feedstock grind.

- Grinder: Name of the grinder manufacturer and model number.

- Bale Number: A unique bale identification number that is traceable back to a feedstock and its moisture. By tracking the bale number and grinder performance parameters, grinding efficiencies for feedstock's and moistures can be developed.

- Engine Temperature: This temperature $(F)$ is of interest due to the nature of the grinding process and the material being ground. Under certain conditions, various feedstock fines have been known to be a fire hazard when they accumulate on hot surfaces.

- Engine Housing Temperature: In addition to recording temperatures of the engine, other areas of the grinder will also be measured to determine operating temperatures. This temperature is of interest due to the nature of the grinding process and the material being ground. Under certain conditions, various feedstock fines have been known to be a fire hazard when they accumulate on hot surfaces. When the testing begins, temperatures of various (TBD) components will be measured.

- Screen Size: The screen is sized with openings to allow a certain size fraction to be processed during the grinding operation. The measurement of the screen size will be recorded.

- Opening Shape: Screen opening shapes can be variations of round (oval), square (rectangular), or other geometric shapes that can be cut or machined into the steel screens. 
The screen opening shape adds a degree of variation to the filtering or sieving of the ground fractions. The screen opening shape will be recorded.

- Conveyor speed: The speed of the conveyor belt will be recorded.

- Bale Feed Time: Bale feed time is the time it takes to feed a bale into the grinder. This time relates to the time it takes to grind a bale. The grinding time varies directly with moisture of the feedstock and the size of the screen. The bale feed time for each bale will be recorded.

- Notes: Note are any additional notations or information required to add clarity to the reader.

\section{Truck/Trailer Loading}

The grinding of 30-tons of feedstock will provide enough material to fully load on a 53-foot trailer. When the last bale of each 30-ton batch is loaded into the grinder, the truck and trailer will be moved from under the discharge chute of the grinder to allow for sampling and other data points to be gathered and recorded. An additional page in the Equipment/Hardware Logbook will be used to record trailer weights, loading time, and unloading time. Figure 12 shows this page.

\begin{tabular}{|c|c|c|c|c|c|c|c|}
\hline \multicolumn{8}{|l|}{ Load Date } \\
\hline \multicolumn{8}{|c|}{ Transport Time } \\
\hline \multicolumn{8}{|l|}{ Grinder } \\
\hline \multicolumn{8}{|c|}{ Driver Name } \\
\hline \multicolumn{8}{|c|}{ Truck Make and Model } \\
\hline \multicolumn{8}{|c|}{$\begin{array}{l}\text { Trailer Size (width, } \\
\text { length, height) }\end{array}$} \\
\hline \multicolumn{8}{|c|}{ Trailer Make and Model } \\
\hline $\begin{array}{c}\text { Sample } \\
\text { Material }\end{array}$ & $\begin{array}{l}\text { Moisture, } \\
\text { (\%) }\end{array}$ & $\begin{array}{c}\text { Tare } \\
\text { Weight, } \\
\text { (lbs) }\end{array}$ & $\begin{array}{c}\text { Gross } \\
\text { Weight, } \\
\text { (lbs) }\end{array}$ & $\begin{array}{c}\text { Net } \\
\text { Weight, } \\
\text { (lbs) }\end{array}$ & $\begin{array}{c}\text { Loading } \\
\text { Time, } \\
\text { (min:sec) }\end{array}$ & $\begin{array}{c}\text { Unloading } \\
\text { Time, } \\
\text { (min:sec) }\end{array}$ & Notes \\
\hline $\begin{array}{l}\text { Sorghum } \\
\text { Stover }\end{array}$ & 35 & 47800 & 85500 & 37700 & $42: 39$ & $5: 17$ & \\
\hline $\begin{array}{l}\text { Sorghum } \\
\text { Stover }\end{array}$ & 65 & 47800 & 85500 & 37700 & $35: 08$ & $6: 52$ & \\
\hline
\end{tabular}

Figure 12. An example of truck and trailer page in the Equipment/Hardware Logbook.

A legend of the column headings and the definitions of the headings are listed below:

- Load Date: The date that the load is transported recorded as mm/dd/yyyy.

- Transport Time: The time when the load is moved recorded as military time (8:00 AM is 8:00, but 8:00 PM is 20:00).

- Grinder: Name of the grinder manufacturer and model number.

- Driver Name: This is the name of the operator who is moving the load.

- Truck Make and Model: Write the make and model of the truck.

- Trailer Size: Write the dimensions of the trailer (i.e. width, length, and height). 
- Trailer Make and Model: Write the make and model of the trailer.

- Sample Material: Sample material by variety such as wheat, corn stover, sorghum stover, etc.

- Moisture: This is the percent moisture of the feedstock being ground.

- Tare Weight, pounds: This is the empty weight, in pounds, of the truck/trailer.

- Gross Weight: Total (gross) weight of the truck/trailer after it is loaded with ground material.

- Net Weight: The net weight of the ground material needed to complete the mass balance.

- Loading Time: Total time in minutes and seconds to grind and load the trailer with material.

- Unloading Time: Total time in minutes and seconds to unload the trailer of ground material. This data helps in calculating the efficiencies of unloading.

- Notes: Note are any additional notations or information required to add clarity to the reader.

\section{Sample Logbook}

The Sample Logbook will contain the tracking records for all feedstock samples collected for later laboratory analysis. During the staging effort of the test there are core samples of the bales to be collected. The page in the logbook used to record the coring activities is shown in Figure 13.

\begin{tabular}{|c|c|c|c|c|c|c|}
\hline \multicolumn{2}{|c|}{ Sample Date } & \multicolumn{5}{|l|}{$7 / 17 / 2007$} \\
\hline \multicolumn{2}{|c|}{ Sample Time } & \multicolumn{5}{|l|}{$13: 45$} \\
\hline \multicolumn{2}{|l|}{ Grinder } & \multicolumn{5}{|c|}{ "Manufacturer name and model number" } \\
\hline $\begin{array}{l}\text { Bale } \\
\text { No. }\end{array}$ & Feedstock & $\begin{array}{l}\text { Feedstock } \\
\text { Moisture }\end{array}$ & $\begin{array}{c}\text { Core Sample } \\
\text { Container }\end{array}$ & $\begin{array}{c}\text { Core Sample } \\
\text { Numbers }\end{array}$ & $\begin{array}{c}\text { Core Sample } \\
\text { Locations }\end{array}$ & Notes \\
\hline \multirow[t]{2}{*}{ WS-45 } & $\begin{array}{l}\text { Wheat } \\
\text { Straw }\end{array}$ & $20 \%$ & 2-gal bag & CWS-45-1 & Edge & \\
\hline & “ & “ & “ & CWS-45-3 & Mid Point & \\
\hline
\end{tabular}

Figure 13. Preliminary data

A legend of the column headings and the definitions of the headings are listed below:

- Sample Date: All dates will be recorded as mm/dd/yyyy.

- Sample Time: Recorded military time of sample (8:00 AM is 8:00, but 8:00 PM is 20:00).

- Grinder: Name of the grinder manufacturer and model number.

- Bale Number: A unique bale identification number that is traceable back to a feedstock and its moisture. By tracking the bale number and grinder performance parameters, grinding efficiencies for feedstock's and moistures can be developed.

- Feedstock: Need to list the feedstock variety (corn stover, wheat straw, switchgrass, etc.).

- Feedstock Moisture: This is the moisture of the feedstock material. 
- Core Sample Container: Write the type of core sample container (bucket, bag, etc.).

- Core Sample Numbers: Generate three unique core sample numbers. The core sample specimens need to be linked on paper to a bales number and feedstock.

- Core Sample Locations: The cores will be drilled at three locations: center, mid-point (between the center and edge), and the edge of the test bales.

- Notes: Notes are any additional notations or information required to add clarity to the reader.

During the staging effort of the test, bale moisture readings of selected bales are to be collected. The page in the logbook used to record the moisture reading activities is shown in Figure 14.

\begin{tabular}{|c|c|c|c|c|c|c|}
\hline \multicolumn{2}{|c|}{ Sample Date } & \multicolumn{5}{|l|}{$7 / 17 / 2007$} \\
\hline \multicolumn{2}{|c|}{ Sample Time } & \multicolumn{5}{|l|}{$13: 45$} \\
\hline \multicolumn{2}{|c|}{ Grinder } & \multicolumn{5}{|c|}{ "Manufacturer name and model number" } \\
\hline $\begin{array}{l}\text { Bale } \\
\text { No. }\end{array}$ & Feedstock & $\begin{array}{l}\text { Feedstock } \\
\text { Moisture }\end{array}$ & $\begin{array}{c}\text { Moisture } \\
\text { Sampling } \\
\text { Device }\end{array}$ & $\begin{array}{l}\text { Moisture } \\
\text { Sample } \\
\text { Numbers }\end{array}$ & $\begin{array}{c}\text { Moisture } \\
\text { Sample } \\
\text { Locations }\end{array}$ & Notes \\
\hline \multirow[t]{3}{*}{ WS-45 } & $\begin{array}{l}\text { Wheat } \\
\text { Straw }\end{array}$ & $20 \%$ & Model xx & MWS-45-1 & Edge & \\
\hline & “ & “ & Model xx & MWS-45-3 & Mid Point & \\
\hline & “ & “ & Model xx & MWS-45-2 & Center & \\
\hline
\end{tabular}

Figure 14. Preliminary data

A legend of the column headings and the definitions of the headings are listed below:

- Sample Date: All dates will be recorded as mm/dd/yyyy.

- Sample Time: Recorded military time of sample (8:00 AM is 8:00, but 8:00 PM is 20:00).

- Grinder: Name of the grinder manufacturer and model number.

- Bale Number: A unique bale identification number that is traceable back to a feedstock and its moisture. By tracking the bale number and grinder performance parameters, grinding efficiencies for feedstock's and moistures can be developed.

- Feedstock: Need to list the feedstock variety (corn stover, wheat straw, switchgrass, etc.).

- Feedstock Moisture: This is the moisture of the feedstock material.

- Moisture Sampling Device: Name of the sampling device.

- Moisture Sample Numbers: Generate three unique moisture sample numbers. The moisture sample specimens need to be linked on paper to a bales number and feedstock.

- Moisture Sample Locations: The cores will be drilled at three locations: center, mid-point (between the center and edge), and the edge of the test bales. 
- Notes: Notes are any additional notations or information required to add clarity to the reader.

This logbook also records sample data taken during the grinding operation. Figure 15 shows a sample of this logbook page.

\begin{tabular}{|l|l|l|l|l|l|c|c|c|}
\hline \multicolumn{2}{|l|}{ Sample Date } & \multicolumn{2}{l|}{$7 / 17 / 2007$} \\
\hline \multicolumn{2}{|l|}{ Sample Time } & \multicolumn{1}{l|}{$13: 45$} \\
\hline Grinder & "Manufacturer name and model number" \\
\hline $\begin{array}{c}\text { Bale } \\
\text { Number }\end{array}$ & $\begin{array}{c}\text { Sample } \\
\text { Number }\end{array}$ & $\begin{array}{c}\text { Sample } \\
\text { Material }\end{array}$ & $\begin{array}{c}\text { Sample } \\
\text { Moisture } \\
(\%)\end{array}$ & $\begin{array}{c}\text { Screen } \\
\text { Size }\end{array}$ & $\begin{array}{c}\text { Sample } \\
\text { Container }\end{array}$ & $\begin{array}{c}\text { Sample } \\
\text { Type }\end{array}$ & $\begin{array}{c}\text { Sample } \\
\text { Location }\end{array}$ & Notes \\
\hline & & & & & & & & \\
\hline
\end{tabular}

Figure 15. An example of sample logbook page.

A legend of the column headings and the definitions of the headings are listed below:

- Sample Date: All dates will be recorded as mm/dd/yyyy.

- Sample Time: Recorded military time of sample (8:00 AM is 8:00, but 8:00 PM is 20:00).

- Grinder: Name of the grinder manufacturer and model number.

- Bale Number: A unique bale identification number is traceable back to a feedstock and its moisture. By tracking the bale number and the engine performance, grinding efficiencies for feedstock's and moistures can be developed.

- Sample Number: The sample number will be a unique number or identifier. The number will be used to track and link samples to feedstock types and varieties.

- Sample Material: The feedstock variety.

- Sample Moisture: This is the percent moisture of the sample material.

- Screen size: The screen is sized with openings to allow a certain size fraction to be processed during the grinding operation. With small screen, the finer the size fraction will be, but with smaller openings, longer grinding times are required to get the small sizes. The measurement of the screen size will be recorded.

- Sample Container: Enter the sample container type (i.e.: 2-gallon Ziploc type bag, 5-gallon plastic bucket or super sack).

- Sample Type: The sample type is descriptive to the sample taken: bucket, bag, sack, or core sample. The sample type will be listed.

- Sample Location: The sample location will be recorded. The location is a descriptive to where the sample is taken: mid-stream, middle, edge or random, etc.

- Notes: Notes are any additional notations or information required to add clarity to the reader. 


\subsubsection{Photographs}

Digital cameras will be available to take photographs and video clips of all aspects of the grinding operation. This includes the bale handling, screen changing, discharge of ground material, sampling, etc.

Photographs of the bales and stacks of bales will also be taken prior to the start of the grinding tests for subsequent use in the test reports.

\subsubsection{Feedstock Moisture/Temperature Probes}

Feedstock moisture in an important component of the processing tests. Preliminary tests of commercial grinding equipment indicate that moisture in the bales can have a significant effect on total throughput or tons/hour of ground material. Moisture readings from bale will be collected on the day of the grinding test. Three moisture probes will be available and calibrated for this test. An example of a commercial moisture probe with sensor is shown in Figure 16.
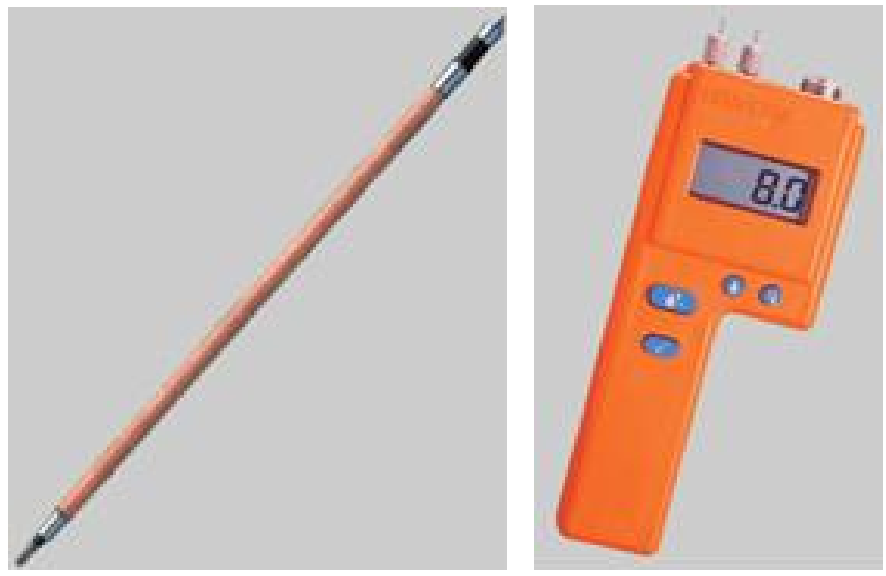

Figure 16. Moisture reading system: probe and meter

Temperatures of feedstock before and after grinding are taken to ascertain if the grinding temperatures are harmful to the quality of the ground material. A calibrated digital thermometer will be used to gather temperature readings. An example of the digital thermometer probe is shown in Figure 17.

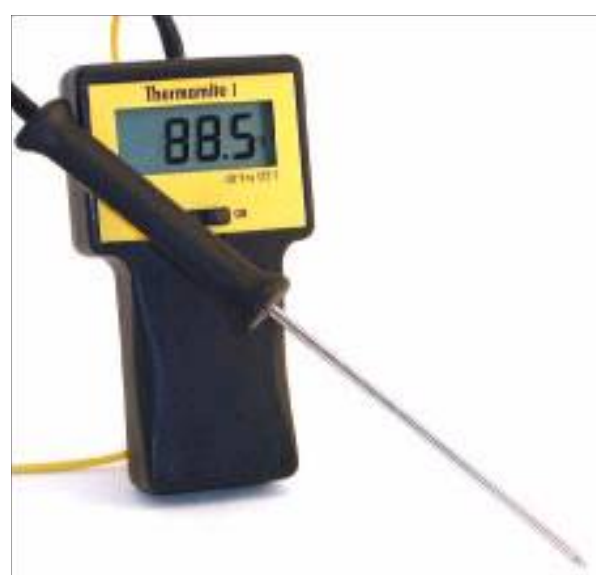

Figure 17. Commercial temperature reading system: probe and meter 


\subsubsection{Portable Scale}

The portable truck scale that is installed at the test site will be used to obtain tare and gross weights of the trucks and trailers. The INL scale will be installed at the test site and used throughout the test. The weights of the bales or groups of bales needs to be obtained, but this is to be determined later.

\subsubsection{Capture Material Grind Samples}

Capturing samples is a composite of several related sub-activities. These include:

- Operational safety meeting

- Sample collection

- Sample containers

- Sample container labels

- $\quad$ Shipping

\subsubsection{Operational Safety Meeting}

Prior to starting the grinding operation and taking of samples, a meeting of all on-site project personnel will discuss in an organized training session any operational, safety and sample taking issues to ensure the tests and associated sampling can be performed adequately and in a safe manner. Part of the discussion will include the appropriate personal protective equipment: eye protection, hearing protection, hard hats, etc. A summary of the meeting, the material covered and a list of the attendees will be recorded in the Field Team Leaders Narrative Logbook.

\subsubsection{Sample Collection}

Grinding 30-tons of one of the six feedstocks is expected to take about one hour to complete. Between two and six bucket samples will be taken during the grinding operation of each 30-ton batch. The samples will be taken mid-stream as the ground material is expelled from the discharge chute. The technician will stand near the discharge chute and maneuver the sample bucket into the flow of ground material to fill the bucket. A simple diverter device may be designed and constructed by the INL to assist in this operation. Bag samples may also be captured in midstream directly or can be loaded from a bucket. The technician will be wearing the appropriate personal protective equipment during the capturing of the samples: eye protection, hearing protection, hard hat, etc.

To ensure the chain of custody between the sample and the container is not lost, identical (duplicate) labels for each bucket or bag will be attached on both the inside and outside of the container before capturing the samples. As samples are captured, they are to be issued a number and that number with the feedstock data will be entered into the Sample Logbook.

Super sack samples will be taken at the end of the 30-ton grinding batch. When the last bale is loaded into the grinder, the truck and trailer will be moved out of the way. A forklift with a super sack hung from the forks, will be moved in place under the discharge chute and filled with the ground feedstock from the last bale of the batch.

\section{Airborne Particle Samples}

Airborne particulate samples will help quantify what is being lost, in terms of the composition of the feedstock particles, during the grinding operation. These losses in conjunction with the mass balance 
calculations will help quantify the cost and quality the ground material for each feedstock variety and moisture. INL will provide a vacuum collection system capable of collecting airborne particulate samples during the grinding test. After each 30-ton grind is completed, the particulate sample will be placed in a 2 gallon Ziploc type bag and given both a sample number and a tracking label. These samples will then be analyzed for particle size/distribution and composition.

\section{Core Samples}

Core samples of selected bales will be collected prior to the grinding tests. The samples will be used as a baseline for comparison of the material before and after grinding. Core samples will be taken with a coring tool attached to a 3/4-inch drive electric drill (See Figure 18). A portable generator will be available at the site if there are no other electrical power options.

Three core samples (about 1 liter $\left(60 \mathrm{in}^{3}\right)$ of material) will be taken from three different bales in each 30 -ton supply ( $\sim 60$ bales) of feedstocks. The three cores will be randomly taken from the approximately 60 bale batch. The cores will be drilled at three locations: center, mid-point (between the center and edge), and near the edge. As the cores are taken, a unique number will be given to each core and it will be recorded in the logbook linking it to the bale number. Each sample will be packaged into a 2-gallon Ziploc type bag with an appropriate sample label. Core samples of the baled material will be collected prior to grinding.

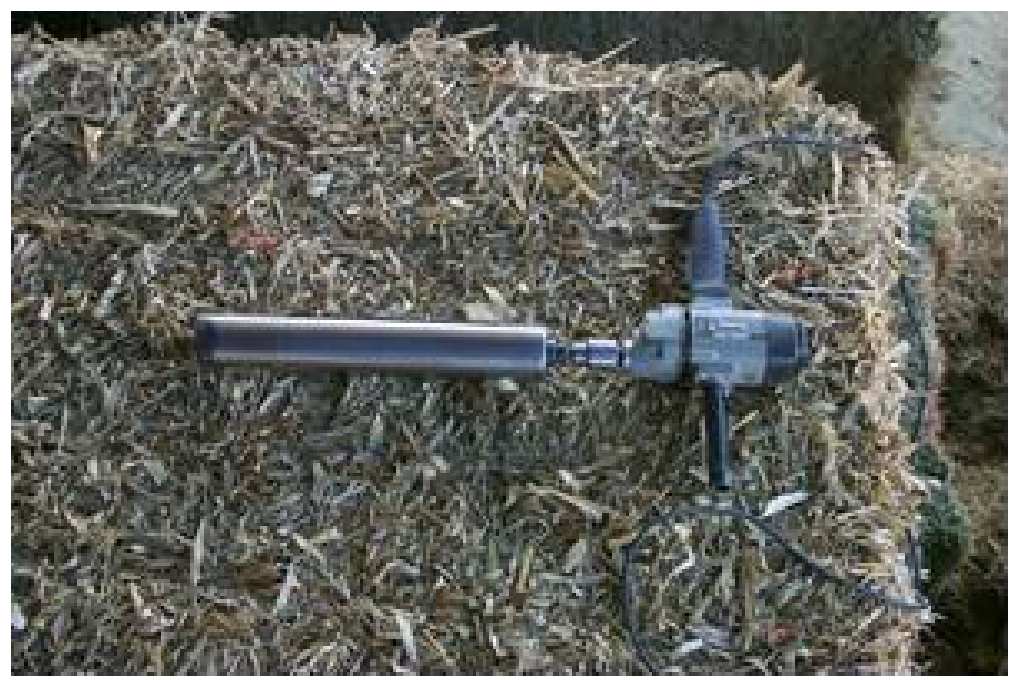

Figure 18. Coring tool and portable electric drill.

\subsubsection{Sample Containers}

The sample containers need to be staged at the test location prior to the test grind. The sample containers for this project include:

- 30 Gallon Drums: Plastic 30 gallon drums will hold the ground material from each grinding set. These plastic drums will also double as shipping containers.

- 5-Gallon Plastic Buckets: Buckets with sealable lids and bail handles will be used to collect a number of samples during the grinding tests. These buckets also double as shipping containers.

- Bags: Two gallon Ziploc type bags are used from smaller samples in the grinding tests. These bags can be placed into buckets, boxes or coolers for shipping. 


\subsubsection{Sample Container Labels}

For sample management and tracking purposes, pre-printed sample labels will be used. Templates for the sample labels are located in Appendix A. The template uses the 3.3 X 4-inch Avery Shipping Label, No. 6464. Figure 19 shows the proposed sack/bucket/bag sample identification label.

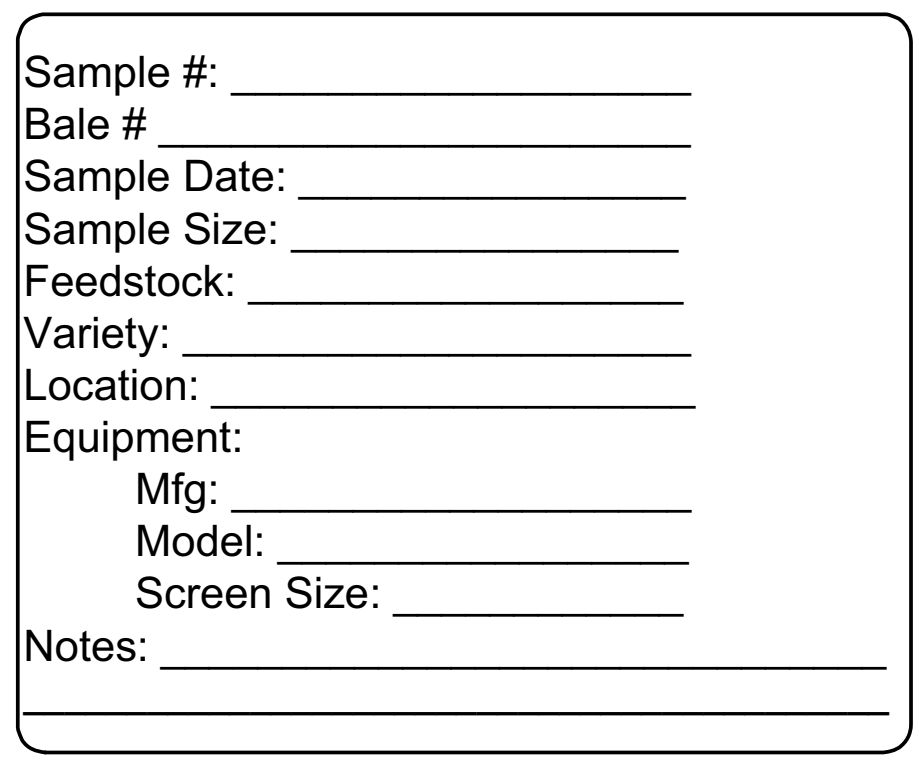

Figure 19. Example of sample container label

\subsubsection{Shipping}

Plastic buckets make excellent shipping containers for feedstock material. They are inexpensive, readily available, sturdy, and double as both the sample and shipping container. Multiple 2-gallon bag samples can be placed into a bucket, cardboard box or polyethylene cooler for shipping. Packing tape will be liberally used to wrap around the lid and bucket to ensure the lid does not separate during shipment. Buckets will be shipped directly to the INL using FedEx pre-paid shipping labels to greatly aid in the shipping process. Super sack samples, if required, will be shipped to an INL feedstock storage site in Terreton, Idaho.

After all of the 30-ton batches of feedstock are ground, the samples taken will be shipped to the predetermined locations. The samples captured during the mobilization phase of the test will be included with the full scale samples for shipping. Buckets will be shipped via FedEx, but super sacks will be freighted in a private commercial transporter.

\subsubsection{Sample Ownership}

All samples collected under this test plan will be the property of the INL and the specific grinder manufacturer. Samples will be shipped to the INL or INL designated facilities for analysis and characterization. Samples not by the INL or the grinder manufacturer prior to the execution of the test plan may or may not be labeled, logged, tracked, or analyzed by the INL according to the procedures presented in this plan. 


\subsubsection{Conduct Data Reduction and Sample Analysis}

The data reduction and sample analysis is beyond the scope of this test plan, but this needs to be conducted to meet the following goals of the test:

- Establish a capacity measurement per ton/hour $/ \mathrm{kW}$

- Establish an operational efficiency

- Assess commercially available hammer and fixed cutter grinder technologies

- Measure a grinding variability of feedstock moistures

- Measure a grinding variability of feedstock varieties

- Conduct a sensitivity analysis of feedstock moistures/varieties to parameters

- Define a total grinding, transporting and handling cost.

\section{SAFETY AND QUALITY ASSURANCE}

\subsection{Safety}

For the Machine Characterization Test, safety training will be conducted by the grinder manufacture prior to starting the grinding tests. The training will cover the topics of:

- Personal protective equipment: hearing, clothing, eye protection, etc

- Fire watch, fire protection, fire extinguishers, etc

- First aid kits

- Storm and tornado warning signals

- Local hospital and emergency room locations

- Emergency responder contact numbers

- Detailed explanations of hammer and fixed cutter grinder hazards

The training will include all of the teams and personnel who are involved with the grinding operation. Safety training for the sample capturing activities will be conducted by the INL team and will include those who support the sample capturing activities.

\subsection{Quality Assurance}

Since the feedstock preprocessing tasks are a field test, defined QA requirements are not required. The taking of ground samples and the subsequent shipping of samples will follow established INL protocol for sample management, chain of custody, and tracking.

\subsubsection{Quality Level}

The quality level of items and activities for this test plan has been defined as quality level three. 


\subsubsection{Measuring and Test Equipment}

The measuring and test equipment (M\&TE) used in this test plan will have current calibrations.

\section{LIST OF TOOLS}

For any field test there are many tools required to operate and maintain the test. But this list of tools is only for the field tools and equipment required for the data gathering and capturing of material samples. This list does not include anything in the INL mobile laboratory (i.e., laptops, printers, etc.).

- Digital camera

- Video recorder

- Electric drill and core drill tool

- $\quad$ Dust sampling tool

- Digital thermometer

- Digital moisture probe

- Stop watches

- $\quad$ Timers

\section{REFERENCES}

1. Biomass as Feedstock for a Bioenergy and Bioproducts Industry: The Technical Feasibility of a Billion-Ton Annual Supply, USDOE and USDA April 2005

2. Breaking the Biological Barriers to Cellulosic Ethanol, a Joint Research Agenda, a Research Roadmap Resulting from the Biomass to Biofuels Workshop December 7-9, 2005, DOE/SC0095, June 2006

\section{CONTACT PERSONS}

Table 6. Test plan point of contact list.

\begin{tabular}{|l|l|l|l|l|}
\hline Order & \multicolumn{1}{|c|}{ Name } & \multicolumn{1}{c|}{ Email } & \multicolumn{1}{c|}{ Company } & \multicolumn{1}{c|}{ Phone } \\
\hline 1 & Christopher Wright & Christopher.Wright@inl.gov & INL & $\begin{array}{l}\text { (208) 526-3075 Voice } \\
(208) 521-0195 \text { Cell }\end{array}$ \\
\hline 2 & Patrick Laney & Patrick.Laney@inl.gov & INL & (208) 526-7468 Voice \\
\hline 3 & Kevin L Kenney & Kevin.Kenney@inl.gov & INL & $\begin{array}{l}\text { (208) 526-8098 Voice } \\
(208) 520-0233 \text { Cell }\end{array}$ \\
\hline 5 & Richard Hess & JRichard.Hess@inl.gov & INL & $\begin{array}{l}\text { (208) 526-0115 Voice } \\
(208) 521-8585 \text { Cell }\end{array}$ \\
\hline 6 & Pete Pryfogle & Peter.Pryfogle@inl.gov & INL & $\begin{array}{l}\text { (208) 526-0373 Voice } \\
(208) 569-9018 \text { Cell }\end{array}$ \\
\hline 7 & Dave Muth & David.Muth@inl.gov & INL & (208) 526-0963 Voice \\
\hline
\end{tabular}

